\title{
Visões do gosto arquitetônico passadista: problematizando o "estilo neoclássico" de São Paulo em perspectiva internacional'
}

\begin{abstract}
Carolina Pulici²
RESUMO: Em vista de uma pesquisa mais ampla sobre os condicionantes socioculturais da proliferação dos edifícios ditos "neoclássicos" na arquitetura de apartamentos de São Paulo, este artigo discute diferentes abordagens do que se poderia chamar de gosto arquitetônico passadista. $\bigcirc$ balanço bibliográfico resultante apresenta uma literatura produzida especialmente na Europa e nos Estados Unidos a partir do último quartel do século XX, período em que o questionamento da estética moderna do despojamento e a volta dos ornamentos e da linguagem historicista tornam-se evidentes na cena arquitetônica internacional.

PALAVRAS-CHAVE: Gosto arquitetônico. Reação ao modernismo. Embalagem historicista. Fabricação de tradições. São Paulo. Apartamentos.

ABSTRACT: In order to contemplate a broader research on the sociocultural conditions of the proliferation of the so-called "neoclassic" buildings in São Paulo's residential architecture, this article discusses various approaches of what can be defined as a backward-looking architectural taste. The resulting bibliographical review presents a literature mainly published in Europe and in the United States since the last quarter of the 20th century, when the reaction to the sober modern aesthetics and the return of the ornaments and of the historicist language became evident in the international architectural scene.

KEY-WORDS: Architectural taste. Reaction to modernism. Historical packaging. Manufacture of traditions. São Paulo. Apartments
\end{abstract}

Introdução

Estudos sobre os padrões de gosto arquitetônico das elites brasileiras revelam renitente ausência de aspiração vanguardista no que tange à estética do projeto de residência estimado, e tal inclinação passadista dá-se a ver no servilismo
1. Este artigo apresenta resultados parciais de uma pesquisa de pós-doutorado intitulada $A$ consagração social de um gosto controverso: prédios neoclássicos no espaço residencial das elites de São Paulo, desenvolvida no Museu Paulista da Universidade de São Paulo entre 2011 e 2012 sob os auspícios da FAPESP.

2. Professora de Sociologia do curso de Ciências Sociais da Universidade Federal de São Paulo (UNIFESP). E-mail: <carolinapulici@ gmail.com>. 
3. Ver José Carlos Durand (1989) e Silvia Ferreira Santos Wolff (2001).

4. A esse respeito ver, por exemplo, Nestor Goulart Reis Filho (1987) e Gregori Warchavchik (2006).

5. Ver Fernando Serapião (2011).

6. Ver Heloísa Helvécia (2008).

7. Ver Fernando Serapião (2004).

8. Ver Simone Barbosa Villa (2006).

9. Ver. Mariana Barros e Silas Martí (2009).

10. Esse processo de "alquimia social" que opera a separação da fabricação do bem material e a produção do bem simbólico foi discutido por Pierre Bourdieu e Yvette Delsaut em estudo sobre a produção da crença no mundo da moda: "O trabalho de fabricação propriamente dito não é nada sem o trabalho coletivo da produção do valor do produto e do interesse pelo produto, isto é, sem o conluio objetivo dos interesses que alguns dos agentes, em razão da posição que ocupam em um campo orientado para a produção e circulação deste produto, possam ter em fazer circular tal produto, celebrá-lo e, assim, apropriar-se dele simbolicamente, além de desvalorizar os produtos concorrentes, isto é, celebrados por concorrentes, e assim por diante" (2006 [1975], p. 163-164). aos padrões europeus de "bom gosto" e à vida aristocrática que presumem simbolizar ${ }^{3}$. A "imitação mal feita" de modelos estrangeiros de moradia é tema que percorre toda a história da arquitetura feita no Brasill e, ainda que sob novas roupagens, um processo análogo é comumente relacionado à proliferação de edifícios residenciais ditos "neoclássicos" na São Paulo contemporânea.

Para arquitetos e críticos de arquitetura brasileiros filiados aos princípios do moderno, o "neoclassicismo" que só faz crescer na paisagem arquitetônica paulistana não passaria de cópia espúria ${ }^{5}$ que homenageia uma linguagem anacrônica e enfatiza a fachada "nobre" sedutora de uma elite de "dinheiro novo" empenhada em comprar um passado heráldico". "Fraudulentos", tais prédios pecariam em sua volumetria e excessiva licenciosidade, misturando elementos da arquitetura clássica com pináculos e mansardas parisienses ${ }^{7}$. Tais análises enfatizam a servidão às leis mercadológicas que teriam transformado a arquitetura num "produto"8 de qualidade e de gosto duvidosos?.

Muito embora esse seja, pois, um tema recorrente na fala dos arquitetos brasileiros contemporâneos, sua abordagem é invariavelmente marcada pela desqualificação indignada, de modo que até o momento muito pouco se conhece do processo coletivo de consagração desse bem econômico e simbólico que, em grande medida, viabiliza-se socialmente a despeito de suas desdenhadas propriedades intrínsecas. Admitindo-se a dupla natureza dos bens simbólicos, temse que os circuitos de produção e circulação material são simultaneamente ciclos de consagração que produzem legitimidade e, assim, o princípio da eficácia dos prédios "neoclássicos" não deveria ser buscado apenas em suas características formais e construtivas, mas nas condições sociais que produzem a crença nesse estilo residencial ${ }^{10}$.

Se é assim - e se a crítica de arquitetura brasileira dedicada aos edifícios de inspiração neoclássica restringe-se à análise formalista de seus famigerados "desvios" construtivos -, o estudo da consagração social desse gosto controverso exige que se faça, de saída, uma revisão das fontes bibliográficas estrangeiras voltadas às manifestações de historicismo arquitetônico no século XX e, sobretudo, à própria gênese social dos gostos em matéria de moradia.

balanço da literatura empreendido (e a ser apresentado a seguir) permitiu identificar diferentes abordagens do que poderia ser considerado um gosto arquitetônico passadista. Há, em primeiro lugar, aquela feita geralmente por arquitetos, historiadores e críticos da arquitetura e que tende a tratar o fenômeno do ponto de vista de uma reação "pós-moderna" à estética moderna, acentuandose, uma vez mais, suas dimensões formais e construtivas, ainda que sem deixar de discutir a formação das preferências dos habitantes. Outra vertente reúne as análises dedicadas ao final do século XIX e início do século XX e levadas a cabo por historiadores da cultura. Nessa perspectiva, apreende-se o historicismo arquitetônico como equivalente arquitetural de valores, mentalidades e visões de mundo que remetem a uma realidade muito mais ampla, como o processo de modernização industrial então em curso, as estratégias de distinção vigentes nas relações de classe 
ou a transformação nos regimes políticos. Finalmente, e mais apropriada aos objetivos da pesquisa que deu ensejo a este balanço, existe ainda a corrente adotada por sociólogos da cultura e que analisa o universo da arquitetura e da construção como "campo", isto é, levando-se em conta as práticas de todos agentes envolvidos com o poder social de construir (engenheiros, construtores, arquitetos, agentes imobiliários, publicitários, poderes públicos), o que exige investigar suas posições relativas e as respectivas tomadas de posição no âmbito desse universo de produtores-adversários: dado que o valor distintivo de um produto é sempre relacional, isto é, relativo à estrutura do campo em que se define, tal abordagem apreende as formas por meio das quais os propagadores de um tipo de projeto se diferenciam de seus concorrentes na luta pelo monopólio da legitimidade em matéria de habitação.

Em vista da extensão e da diversidade da bibliografia que direta ou indiretamente trata desse tema que, visto de modo genérico, fez fortuna em diferentes áreas disciplinares, o balanço que segue não é exaustivo nem tampouco se apresenta segundo uma ordem estritamente cronológica. Como a maioria dos levantamentos bibliográficos, este também foi construído a partir de interesses específicos, no sentido de que o rastreamento dos textos atendeu às necessidades de familiarização com os debates concernentes ao problema da pesquisa mais ampla em que se insere, qual seja, o de investigar a gênese sociocultural do gosto "neoclássico" na arquitetura de apartamentos da São Paulo na segunda metade do século XX. A seleção aqui apresentada reúne, assim, estudos publicados principalmente na Europa e nos EUA a partir do último quartel do século passado, período em que o questionamento da estética moderna do despojamento e a volta dos ornamentos e da linguagem historicista tornaram-se evidentes na cena arquitetônica internacional.

Historicismo "pós-moderno" e desencanto com o modernismo

Enquanto um tribunal de justiça se parecer com uma agência bancária qualquer, enquanto uma escola primária se parecer com uma fábrica, enquanto uma nova cidade se parecer com uma feira de exposição, o fosso continuará a se aprofundar entre a arquitetura "moderna" dos arquitetos e um público que não a reconhecerá jamais como sua".

Bernard Huet

Aceitando-se o pressuposto de que toda proposta cultural se define, sobretudo, naquilo que recusa ${ }^{12}$, pode-se dizer que de um modo geral o partido passadista e decorativo que marca uma parte considerável da produção arquitetônica contemporânea situa-se em oposição ao projeto de arquitetura vinculado aos princípios modernistas. Em L'architecture entre goût et opinion: construction d'un parcours et construction d'un jugement, estudo voltado às preferências arquitetônicas dos habitantes de um edifício bastante desacreditado pelos arquitetos franceses (devido ao "ecletismo" construtivo e à permissividade
11. Tradução nossa. No original: "Tant qu'une cour d'appel ressemblera à une quelconque succursale bancaire, tant qu'une école primaire ressemblera à une usine, tant qu'une ville nouvelle ressemblera à un champ de foire-exposition, le fossé continuera de se creuser toujours plus profondément entre l'architecture 'moderne' des architectes et un public qui ne la reconnaîtra jamais comme sienne" Cf. Bernard Huet (1981).

12. Ver Pierre Bourdieu (2005 [2002]). 
13. Trata-se do edifício Apollonia 2, localizado em Courbevoise, município situado a oeste de Paris, na margem esquerda do rio Sena, e inaugurado em 1996.

14. Ver Monique Eleb, Soline Nivet e Jean-Louis Violeau (2005).

15. Tradução nossa. No original: "Autre jugement encore plus courant, l'architecture moderne ne ressemble à rien d'autre qu'à des images négatives, stéréotypées: le HLM, le bunker en béton, etc.”. Cf. Monique Eleb e Soline Nivet \& Jean-Louis Violeau (2005, p. 30).

16. Tradução nossa. No original: "Le beau serait alors l'unifié mais pas le lisse, pas les 'beaux nus tranquilles' tant appréciés par les critiques d'architecture du tournant du XXe siècle. L'absence de décoration ostensible est ainsi vue comme pauvre car les éléments ténus de détails savants ne sont pas lisibles à tous, comme par exemple l'élégance de la minceur des menuiseries, appréciée par les initiés. Le non décoré est alors perçu comme banal, trop simple, sans qualité". Cf. Monique Eleb e Soline Nivet \& Jean-Louis Violeau (2005, p. 60). Os autores argumentam, em várias passagens, que as fachadas protuberantes e com múltiplos elementos decorativos seriam mais interessantes por mobilizarem mais a atenção. Discutindo estudos de psicologia da percepção, lembram que o "grande público" não exposto às escolas e aos movimentos arquitetônicos rejeita a uniformidade das fachadas e as paredes sem ornamentos, pois, enquanto as superfícies planas exigiriam um único centramento do olhar, as formas complexas demandariam muitas fixações do olhar. E, nesse contexto, quanto mais se centra o olhar, mais se formal) mas, no entanto, efusivamente difundido pelos profissionais de marketing na Paris dos anos 2000 '3, Monique Eleb, Soline Nivet e Jean-Louis Violeau ${ }^{14}$ apontaram que a grande maioria dos moradores prefere uma arquitetura ornamentada e rejeita a austeridade das propostas modernas, vistas como algo não aconchegante e não confortável: "Outro julgamento ainda mais comum é o de que a arquitetura moderna não se assemelha a nada mais do que imagens negativas, estereotipadas: o HLM [sigla dos conjuntos denominados Habitação de Aluguel Moderado], o bunker de concreto, etc ${ }^{\prime 15}$. O curioso, segundo os autores, é que o público que julga o moderno um partido submisso a uma geometria fria e abstrata considera que apenas o quadrado e o retângulo sejam formas geométricas, mas não o círculo. Nessa linha de juízo, o ângulo reto seria imposto pelo arquiteto, enquanto o traçado arredondado é avaliado como algo absolutamente natural. Com base em entrevistas junto aos compradores dos apartamentos desse prédio de decoração ostensiva, os autores apuraram que o apego ao ornamental aparece como meio de escapar à banalidade da nudez moderna:

○ belo seria então o unificado, mas não o liso, não os "belos nus tranquilos" tão apreciados pelas críticas de arquitetura da virada do século XX. A ausência de decoração ostensiva é assim vista como pobre, pois os elementos sutis de detalhes eruditos não são legíveis a todos, como, por exemplo, a elegância da delgada espessura dos objetos de marcenaria apreciada pelos iniciados. O não decorado é então percebido como banal, simples demais e sem qualidade ${ }^{16}$.

Na contramão das vanguardas que tendem a reivindicar a autonomia das formas e, assim, uma estética do vazio que se aproxima do minimalismo, o público consumidor desse padrão de arquitetura consideraria tal vazio por demais incomum, ao contrário do carregado, ornado e decorado, estes sim associados ao normal e ao razoável: "Ler e apreciar a 'modernidade plástica' promovida pelas vanguardas continua a ser uma árdua tarefa para os não-especialistas" ${ }^{\prime \prime}$. A recusa de uma estética moderna figuraria, pois, como conjunto de representações partilhado pela maioria dos franceses até os dias atuais, já que as fachadas limpas, sem ornamentação, sempre teriam sido uma posição de vanguarda, "o gosto do público continuando a se dirigir aos signos decorativos que marcam de maneira explícita uma distinção"18. Identificam-se, assim, desejos contraditórios e uma relação ambígua com a arquitetura, iá que o público estaria a dar mostras de querer apenas o conforto do novo, mas desde que aliado à beleza do antigo.

Eleb, Nivet e Violeau avaliam ainda que o gosto por um prédio que prima pela exuberância e pelo "ecletismo" de suas fachadas (providas de colunas em diversas ordens fantasistas, arcadas andaluzas, ferro forjado, balaústres, frontões, pilastras) se inscreve nas estratégias distintivas vigentes nas relações de classe: "Para os proprietários dos apartamentos de Courbevoie, o edifício produz uma impressão de luxo: o imóvel tem "ares" de ser caro. A originalidade é então o indício do nível de qualidade do prédio e, indiretamente, de seus habitantes"19. E o "ar luxuoso" viria justamente da profusão de signos na fachada e do tamanho 
dos halls e dos andares, pois as pessoas ficariam impressionadas com amplos espaços na entrada, levando inevitavelmente a uma apreciação positiva de seus habitantes ${ }^{20}$.

Para os autores, estaríamos diante de prédios "de marca", mas que é antes de tudo a "marca" de um construtor imobiliário, e menos a de um arquiteto. Nesse contexto em que a "grife" de um construtor sobrepõe-se ao desenho do arquiteto, a quantidade de prédios indiscriminadamente nomeados "haussmanianos" na Paris contemporânea dever-se-ia ao fato de os corretores recorrerem a categorias históricas como argumento de venda, fazendo com que todo um conjunto de construções muito díspares seja inserido num mesmo rótulo que, de tão elástico, a rigor inviabilizaria a denominação de "estilo":

O haussmaniano se torna então uma categoria extremamente plástica, quase "genérica", para retomar (de outra forma) a noção formulada por um célebre arquiteto-teórico, Rem Koolhaas. De um lado, o haussmaniano (1853-1871) tornou-se uma sinédoque do conjunto dos edifícios parisienses do século XIX e, de outro lado, usa-se o "estilo" como argumento de venda, jogando com desenvoltura com as categorias históricas /daí a recorrência dos termos marca, charme e caráter...). A promoção imobiliária, em primeiro lugar a Cogedim, que lançou a marca comercial "os bairros haussmanianos", comercializa sob esta denominação uma arquitetura que imita um leque bem mais amplo da arquitetura parisiense do que unicamente o período haussmaniano, com uma constante, o imóvel tripartite (embasamento, andares quadrados, coroamento em mansarda): O "rambutéen" 21 (com janelas palladianas centrais e colunas), o haussmaniano (fachada lisa e aberturas regulares), "o anti-haussmaniano" (fachada protuberante e bow-windows), "o art déco" (geometria acentuada e linhas verticais definidas, azulejos geométricos), etc. Um verdadeiro patchwork, representação banalizada, hoje, da derradeira realização do ecletismo ${ }^{22}$.

Não é um acaso, portanto, que nesse estudo os autores façam referência ao crítico e historiador da arquitetura norte-americano Charles Jencks e ao seu $A$ linguagem da arquitetura pós-moderna (1977): diante do "ecletismo" radical da contemporaneidade, não haveria mais um movimento nem um estilo, mas tãosomente um "gênero", espécie de categoria híbrida, não estática e de contornos bem mais amplos do que os estilos que inclui e mistura. Nessa linha de juízo, os estilos teriam perdido sua significação primeira e se tornado gêneros, "elementos classificatórios de estados de alma e de temas"23.

A ideia de que a arquitetura que emerge nos anos 1970 caracteriza-se por uma mistura de linguagens e de elementos é defendida pelo próprio Jencks em Post-Modernism: The New Classicism in Art and Architecture (publicado em 1987), obra em que o autor se consagra às expressões arquitetônicas do que ele considera que seja o terceiro estágio do pós-modernismo, a saber, o "classicismo pósmoderno" que teria emergido a partir de 1979. Certo de que o pós-modernismo não é anti-modernista nem reacionário, Jencks destaca que o retorno da arquitetura clássica - como da figura humana na pintura - não expressa somente tradição, mas uma tradição que sofre a intervenção do mundo moderno. Ou seja, os valoriza o que se vê (2005, p. 59-60).

17. Tradução nossa. No original: "Lire et apprécier la 'modernité plastique', promue par les avant-gardes, demeure une tâche ardue pour les non-spécialistes". Cf. Monique Eleb, Soline Nivet e Jean-Louis Violeau (2005, p. 69).

18. Tradução nossa. No original: “(...) le goût du public continuant à se porter vers des signes décoratifs qui marquent de façon explicite une distinction". Cf. Monique Eleb, Soline Nivet e JeanLouis Violeau (2005, p. 69). Sobre o decorativismo "velado" da arquitetura moderna ver Sylvia Ficher (1985). Para uma análise de como a recusa de intenção plástica como um fim em si mesmo reivindicada pela arquitetura funcionalista não é mera subordinação às necessidades técnicas, podendo, ao contrário, tornar-se um formalismo ver Louis Pinto (1991).

19. "Pour les propriétaires des appartements de Courbevoie, leur immeuble dégage une impression de luxe: leur immeuble a 'l'air' cher. L'originalité est alors le signe du niveau de qualité de l'immeuble, et par ricochet, de ses habitants". Cf. Monique Eleb, Soline Nivet e Jean-Louis Violeau (2005, p. 99).

20. O enobrecimento de imóveis coletivos mediante a adoção de fachadas exuberantes e a adaptação de elementos da arquitetura palaciana deita raízes na história da arquitetura. Tendo insistido na subserviência cultural do emergente homem de classe média da Viena da segunda metade do século XIX, Carl Schorske mostra como o caráter aristocrático dos edifícios residenciais da sociedade da Ringstrasse foi estabelecido primeiro $\mathrm{e}$ principalmente por meio de suas fachadas (mesmo que tal enobrecimento fosse 
frequentemente enganoso, isto é, efetivamente "de fachada"). Em áreas ainda mais socialmente exclusivas como a Reichsratsstrasse, a adaptação de elementos da arquitetura palaciana aos prédios de apartamentos também foi estratégia a que recorreram os arquitetos da época com o fito de nobilitar a fisionomia dos edifícios $\mathrm{e}$ aumentar o seu valor de mercado: "Os arquitetos aperfeiçoaram plantas baixas com o máximo possível de apartamentos em ângulo reto com a rua, de modo a repartir as bênçãos privilegiadas de janelas frontais e, assim, aumentar o valor dos aluguéis. Não era preciso que as características 'enobrecedoras' que aumentavam o preço do aluguel estivessem dentro dos apartamentos individuais" [tradução da edição brasileira de 1988, p. 68-69]. No original: "Architects developed floor plans placing as many apartments as possible at right angles to the street in order to distribute the prestigious blessings of façade windows and thus maximize rental values. 'Ennobling' features that increased the rental yield did not have to be located in the individual apartment units. Imposing stairwells and large vestibules became favored devices from palace architecture to the apartment house". Cf. Carl Schorske (1981, pp. 50-51)

21. Referência à arquitetura de traçado geométrico que integra o conjunto das obras urbanas do prefeito parisiense Claude-Philibert Barthelot de Rambuteau (1833-1848).

22. Tradução nossa. No original: L'haussmannien devient dès lors une catégorie extrêmement plastique, presque 'générique' pour reprendre (autrement) la notion formulée par un architectethéoricien célèbre, Rem Koolhaas. D'une part l'haussmannien (1853-1871) arquitetos identificados ao movimento aceitariam as descobertas do século XX, mas sem fazer delas uma ideologia, no sentido de reconhecerem o débito para com o modernismo e, simultaneamente, almejarem transcender à proposta moderna, remetendo-se a uma linguagem arquitetônica mais ampla.

Em outros momentos, no entanto, o autor se mostra bem mais impiedoso com relação à arquitetura moderna que teria promovido a industrialização e, consequentemente, degradado as comunidades locais e o tecido urbano existente. Certo de que houve uma trágica e fatal associação entre a arquitetura moderna e a modernização - o que não teria sido o caso com outras formas de arte filiadas ao modernismo -, Jencks considera que a emergência da arquitetura e do urbanismo "pós-modernos" dataria do ataque empreendido por Jane Jacobs em 1961 em seu livro The Death and Life of Great American Cities, e nota que a resposta do público às suas próprias análises teria sido extremamente forte em todos os países que visitou e especialmente no mundo comunista, onde a arquitetura moderna foi promovida pelo Estado e tornou-se a única opção de moradia disponível: "O movimento pós-moderno era então, e continua a ser até hoje, um protesto mais amplo contra a modernização, contra a destruição da cultura local pela combinação das forças da racionalização, da burocracia, do desenvolvimento em larga escala e, é verdade, contra o Estilo Internacional Moderno"24.

Um dos testemunhos da ampla aceitação desse movimento teria sido a seção de arquitetura da Bienal de Veneza de 1980 intitulada "A presença do passado", que destacava o historicismo como o elemento mais conspícuo da arquitetura "pós-moderna", expressando o reconhecimento do novo consenso em torno do estilo clássico pós-moderno que, como ele precisa e defende, é distinto da linguagem clássica tradicional. Se, no passado, os vários renascimentos da linguagem clássica associaram-se às antigas normas de perfeição e proporcionalidade, o corpo humano perfeito e a arquitetura perfeita, ambos equivalendo a uma assumida "harmonia cósmica", hoje, quando quase todos os arquitetos pós-modernos adotaram partes do vocabulário clássico, o classicismo não partilharia a crença em um único "simbolismo cósmico". Respondendo às objeções dos que argumentam que o verdadeiro classicismo pressupõe monumentalidade, proporções ideais, solenidade e grandeza, Jencks defende que há monumentalidade, grandeza e solenidade no trabalho de Ricardo Bofill, Philip Johnson e Aldo Rossi e que a falta de proporções ideais deve-se parcialmente ao fato de que a síntese que empreendem não compartilha de uma crença num único "simbolismo cósmico". Este "Free-Style Classicism" seria assumidamente distinto do "Canonic Classicism" de Vitrúvio ou Palladio, já que estaria comprometido simultaneamente com a realidade industrial e com as forças do classicismo, de modo que seria preciso expandir a noção de classicismo:

Ao afirmar uma tradição mais ampla, o Free-Style Classicism expande essa definição de modo a se aproximar mais intimamente da verdade histórica: inventado pelos egípcios, o estilo foi usado em muitos períodos "anti-clássicos" como a época maneirista, e pelo vulgo em construções destinadas à plebe tais como o coliseu e as termas romanas. É esse 
uso mais livre, às vezes vulgar, que é relevante hoje quando arquitetos como Bofill e Stirling constroem para as massas usando materiais não-canônicos como vidro e aço. E esse compromisso tanto com a realidade industrial quanto com o classicismo nos força, como todas as revoluções, a reavaliar nossos termos mais básicos ${ }^{25}$.

Destacando as semelhanças entre os diferentes estilos que recorreram ao clássico, Jencks argumenta que as sérias reservas que Sir John Summerson, autor do célebre The Classical Language of Architecture (publicado em 1963), dirige ao classicismo pós-moderno de Venturi, Moore e Graves lassim como ao trabalho de Bofill) devem-se ao fato dele preferir o classicismo canônico e se orientar por um quadro de referência formado no passado, o que treina inevitavelmente seu olhar de modo a considerar o "Free-Style" esquisito e impuro. Porta-voz assumido do chamado "pós-modernismo", com seus valores de relativismo, gostos plurais e fragmentação da cultura, Jencks avalia que a vida urbana numa sociedade pósindustrial e industrial teria se tornado tão complexa que exigiria uma linguagem igualmente híbrida e suficientemente flexível. Na "era pluralista", diz o autor, os valores absolutos perderam credibilidade e, assim, a "qualidade" pressupõe a mistura de linguagens e de elementos que tanto os modernistas quanto os classicistas canônicos suprimiriam.

No seu modo de ver, um arquiteto como Ricardo Bofill construiria prédios modernistas em trajes clássicos e seu trabalho exibiria um paradoxo típico do pósmodernismo, que é a mistura do mecânico com o voluptuoso, do inflexível com o sensual. Trabalhando o concreto de modo a fazer com que esse material moderno se pareça com a pedra ou o mármore, por exemplo, Bofill teria inventado um novo tipo de textura de concreto e de habilidade industrial cujo charme só poderia ser percebido por um olhar treinado na arquitetura do século XX, e não no ornamento feito à mão. $\bigcirc$ trabalho do arquiteto catalão expressaria, portanto, o débito dos pós-modernistas para com o modernismo e a tradição clássica, num contexto em que as referências e os determinantes formais são "ecléticos" e divergentes, não sendo como no Renascimento em que tudo se enquadrava num sistema metafísico integrado. Realizador do que Jencks chama de a forma mais popular de habitação de massa na França, Bofill teria inaugurado um novo capítulo na história da préfabricação de elementos da arquitetura tradicional ao demostrar a possibilidade de produzir equivalentes de mármore, calcário e stucco lustro - ele próprio falso mármore - usando concreto oxidado fixado em moldes industriais, praticando uma arquitetura que ultrapassa as grandes dicotomias entre classicismo e modernismo, burguês e industrial, individual e produção de massa. Nessa análise de um classicismo parcialmente construído pela máquina Jencks pontua, enfim, que o pósmodernismo arquitetônico enfatiza as virtudes do ornamento simbólico ${ }^{26}$ e ameaça as estéticas integradas devido ao seu radical pluralismo e à sua linguagem híbrida.

Com efeito, estudos voltados ao público da arquitetura corroboram essa visão de que a pré-fabricação de elementos e cenários tradicionais obtém amplo reconhecimento social. Apesar de afirmarem que, de um modo geral, a est devenu une synecdoque de l'ensemble du bâti parisien du XIXe siècle, et d'autre part, on se sert du 'style' comme argument de vente en jouant avec désinvolture sur les catégories historiques (d'où les termes récurrents cachet, charme, caractère...). La promotion immobilière, en premier lieu la Cogedim qui a donc déposé la marque commerciale 'les quartiers h a u s manniens, commercialise sous cette appellation une architecture qui imite un éventail de l'architecture parisienne bien plus large que la seule période haussmannienne avec une constante, l'immeuble tripartite (soubassement, étages carrés et couronnement mansardé): le 'rambutéen' (avec fenêtres à serliennes centrales et à c o 1 o n e t t e $\mathrm{s}$ ), 'l'haussmannien' (façade plate et percements réguliers), '1'antihaussmannien' (façade à saillies et bow-windows), 'l'Art déco' (géométrie accusée et lignes verticales soulignées, faïences géométriques), etc. Un véritable patchwork, représentation banalisée a ujourd'hui d e l'accomplissement ultime de l'éclectisme." Cf. Monique Eleb, Soline Nivet e JeanLouis Violeau (2005, p. 48).

23. Cf. Monique Eleb, Soline Nivet e Jean-Louis Violeau (2005, p. 52).

24. Tradução nossa. No original: "The Post-Modern Movement was then, and remains today, a wider social protest against modernization, against the destruction of local culture by the combined forces of rationalization, bureaucracy, large-scale development and, it is true, the Modern International Style". Cf. Charles Jencks (1987, p. 29).

25. Tradução nossa. No original: "In asserting a wider tradition, Free-Style Classicism expands this definition so it more closely 
approximates the historical truth: invented by the Egyptians, the style was used in many 'anti-classical' periods such as the Mannerist epoch, and by vulgarians on proletariat building tasks such as the Roman thermae and colosseum. It is this freer, sometimes vulgar, usage which is relevant today when architects like Bofill and Stirling build for the masses using non-canonic materials such as glass and steel. And this commitment to both industrial reality and classicism force us, like all revolutions, to reassess our most basic terms. Cf. Charles Jencks (1987, p. 34).

26. O curioso é que o vocabulário clássico que reaparece nesse "estilo clássico pós-moderno" a fim de se opor a um partido arquitetônico pouco ornamentado foi, na França da Restauração, sinônimo de austeridade decorativa. Segundo François Loyer, a Paris neoclássica é justamente a cidade que honra o espírito de despojamento de uma arquitetura que não deve nada ao ornamento que, pelo contrário, é posto de lado em prol de um sistema gráfico marcado por uma geometria abstrata: "O uso de persiana externa é muito mais estilístico, entretanto, do que propriamente técnico: o jogo gráfico que esta propõe anima com discrição superfícies que são despojadas de todo ornamento no estilo neoclássico (...) Num período de austeridade decorativa rigorosa, trata-se de um elemento sutil de animação: o charme de alguns bairros da Paris da época da Restauração (especialmente Saint-Georges) deve-se quase unicamente a essa presença insistente, que unifica os ritmos diversos das fachadas no interior de um sistema decorativo coerente, cujos elementos fundamentais são o grafismo e a horizontalidade. Essa banalidade voluntária de estética de três prédios analisados não é dos aspectos mais considerados pelos moradores, Bernard Barbe e Alain Duclent relatam, em Le vécu de l'architecture (publicado em 1986), que com exceção dos moradores mais desprovidos socialmente - para os quais o custo financeiro conta mais do que as características arquitetônicas -, os pertencentes às altas categorias profissionais compraram um imóvel no famoso conjunto habitacional Les arcades du lac também devido ao interesse pelos projetos do célebre (e controverso) arquiteto Ricardo Bofill. Nesse caso, a arquitetura exterior teria tido um efeito de incitação da aquisição superior ao da disposição interna dos cômodos, reduzida a não mais do que o tamanho do apartamento em metros quadrados. Mesmo se, passado o momento da compra do imóvel, os problemas de arquitetura interior tenham se feito sentir, o renome do arquiteto e a notoriedade de Les arcades du lac acabaram por atenuar as deficiências habitacionais vividas cotidianamente, evidenciando como a arquitetura empenhada na pré-fabricação de uma tradição não tem dificuldade de se legitimar socialmente:

Pelos seus ritmos, suas aberturas, sua modenatura e sua coloração, o desenho das fachadas acentua ainda a referência a modelos urbanos conhecidos e reconfortantes (criando a impressão paradoxal de um "pastiche ${ }^{27}$ jamais visto"). A excepcional qualidade dos painéis da fachada, sua espessura, seu enorme tamanho dão credibilidade à impressão de se estar frente a um conjunto construído de modo tradicional (fachadas que sustentam a edificação, pequenos vãos, arcadas...). Tudo contribui para criar a impressão de que se está em um "pedaço de bairro antigo": aspectos das fachadas, referência clássica dos ornamentos, ruas estreitas, baixa altura dos prédios (térreo mais três andares no máximo), ruas de pedestres, pracinha redonda com arcadas, aberturas estreitas e verticais... etc.; na verdade não é nada disso, o princípio construtivo é contemporâneo e as fachadas são pré-fabricadas ${ }^{28}$.

interesse pela "embalagem estética" dos edifícios também foi notado no estudo da recepção social de outro conjunto habitacional, desta vez um HLM confortável (apartamentos de $126 \mathrm{~m} 2$, mais da metade deles duplex) localizado no 19e arrondissement de Paris. Nessa construção nascida da reabilitação de uma antiga fábrica, "é principalmente na arquitetura externa que parece se situar a qualidade arquitetônica. As pessoas amam os pátios, as passarelas, os espaços plantados, o calor do tijolo de Vaugirard"29. Outra manifestação de importância dada à fisionomia externa dos imóveis exprimiu-se no desgosto pela fachada de concreto aparente e, portanto, por uma estética associada ao modernismo arquitetônico. Apesar dos autores terem concluído que, de um modo geral, a apreciação arquitetônica mais vanguardista tende a ser menos pronunciada entre os mais desfavorecidos socialmente - devido ao fato de os mesmos acreditarem que a planta livre e o uso de metal, por exemplo, evocam demais o universo cotidiano de trabalho (a fábrica) ou mundos com os quais estiveram porventura um dia em contato (a prisão) -, a verdade é que uma fachada de concreto, por exemplo, tende a ser rejeitada pelos mais 
diversos segmentos sociais: "Essa arquitetura (exterior) é, ao contrário, aos olhos de todos, desservida pelo concreto aparente, material cuja aparência causa aversão em todo mundo"30.

A recusa das propostas modernas é corrente na bibliografia empenhada em entender o retorno dos ornamentos na arquitetura contemporânea mundial. Em Les architectes et mai 68, o sociólogo da arquitetura francês Jean-Lovis Violeau tratou dos incentivos ao pastiche e à imitação ao discutir as tomadas de posição dos arquitetos que teriam validado o "ecletismo" que reconcilia a arquitetura com seus habitantes que, em sua grande maioria, nunca conseguiram se afeiçoar pela arquitetura moderna que em princípio deveria thes fazer tanto bem. Philippe Panerai e Jean Castex, por exemplo, teriam questionado o arquiteto que se considera o único detentor da verdade, em detrimento da vontade das pessoas. Nas autoanálises iniciadas em 68 eles teriam dito que "é preciso insistir na responsabilidade dos arquitetos amadores de grandes projetos e concretadores sem ternura" 31 .

Na retrospectiva do pesquisador da École d'Architecture de ParisMalaquais, a defesa do ecletismo aparece também nas análises do arquiteto belga Maurice Culot - para quem a arquitetura funcionalista legitima a ideologia capitalista dominante - e, posteriormente, de Bernard Huet, diante do que considerou a "consternante mediocridade da arquitetura moderna". Para Violeau, ambos teriam incorrido em "paradoxos elegantes" ou "silogismos do tipo: o presente é feio, o passado é belo, então o futuro é o passado" 32. Para Culot, o sistema de referência estética tradicional estaria abolido e, assim, o arquiteto de hoje poderia se exprimir por meio do pastiche sem necessariamente perder sua contemporaneidade: uma construção revestida de uma fachada de painéis sintéticos nos quais é impressa a imagem de uma fachada renascentista poderia se tornar uma criação revolucionária se sua motivação respondesse a uma demanda afetiva e se inscrevesse num esquema funcionalista programado pela análise das relações sociais que o imóvel tem a obrigação de favorecer, ao passo que um imóvel de aspecto moderno poderia constituir um ato reacionário ${ }^{33}$. Huet, por sua vez, avaliou que o pastiche teria a vantagem de uma presença mais discreta na cidade por simular, mediante um mimetismo derrisório, uma relação anacrônica entre tipologia arquitetônica e morfologia urbana:

Mesmo medíocre, ele é obrigado a se situar no interior de uma hierarquia em relação à rua, à praça ou ao monumento, ao passo que a arquitetura dita 'moderna' se esforça em provocar rupturas que parecem ser, para alguns arquitetos, as melhores garantias de uma originalidade que disfarça mal uma falta de criatividade profunda ${ }^{34}$

A tomada de posição estética que faz "a apologia do pastiche" retraduz, segundo Violeau, questões mais amplas que atravessam os campos conexos ao campo propriamente arquitetônico a partir dos anos 1970: engajamentos políticos, vontade de devolver a palavra aos usuários da arquitetura, recursos plásticos mergulha o imóvel no anonimato, ligando-o ainda mais fortemente ao conjunto constituído pela rua ou pelo bairro". Tradução nossa. No original: "Le recours à la persienne extérieure est beaucoup plus stylistique néanmoins, que proprement technique : le jeu graphique que celle-ci propose anime avec discrétion des surfaces qui sont dépouillées de tout ornement, dans l'écriture néo-classique (...) C'est, dans une période d'austérité décorative rigoureuse, un argument subtil d'animation: le charme de certains quartiers Restauration de Paris (notamment, à SaintGeorges) tient presque uniquement à cette présence insistante, qui unifie les rythmes divers des façades à l'intérieur d'un système décoratif cohérent, dont les données fondamentales sont le graphisme et l'horizontalité. Cette banalité volontaire des ressources plastiques plonge l'immeuble dans l'anonymat et le lie ainsi plus fortement encore à l'ensemble constitué de la rue ou du quartier". Cf. François Loyer (1987, p. 96).

27. Para Fredric Jameson, o pastiche é um dos traços ou uma das práticas mais importantes da "pósmodernidade" e envolve, como a paródia, a imitação ou o mimetismo de outros estilos e particularmente dos maneirismos e tiques estilísticos de outros estilos. $\mathrm{O}$ autor precisa, no entanto, que não se pode confundir ou assimilar o termo pastiche ao fenômeno verbal afim que é a paródia: "O pastiche é, como a paródia, a imitação de um estilo singular e exclusivo, a utilização de uma máscara estilística, uma fala em língua morta: mas a sua prática desse mimetismo é neutra, sem as motivações ocultas da paródia, sem o impulso satírico, sem a graça, sem aquele sentimento ainda latente de que existe uma norma, em comparação com a qual aquilo que está sendo imitado é, sobretudo, 
cômico. O pastiche é paródia lacunar, paródia que perdeu seu senso de humor (...)". Cf. Fredric Jameson (1985, p. 18).

28. Tradução nossa. No original: "Le dessin des façades, par ses rythmes, ses percements, sa modénature et sa coloration accentue encore la référence à des modèles urbains connus et rassurants (créant l'impression paradoxale d'un 'Pastiche jamais vu'). L'exceptionnelle qualité des panneaux de façade, leur épaisseur, leur très grande taille accréditent l'impression d'être devant un ensemble construit en 'traditionnel' (façade porteuse, petites portées, arcades...). Tout concoure à créer l'impression que l'on est dans un 'morceau de quartier ancien': aspects des façades, référence classique des ornements, rues étroites, faible hauteur des bâtiments ( $\mathrm{R}+3$ maximum), rue piétonnes, placette ronde avec arcades, percements étroits et verticaux... etc., en fait il n'en est rien, le principe constructif est contemporain et les façades sont préfabriquées". Cf. Bernard Barbe e Alain Duclent (1986, p. 44). O culto da reabilitação ou do pastiche é visto por vários autores como uma especificidade do século XX. Ao discutir as tentativas de ressuscitar as "maisons régionales" na França, André Hernant denuncia esse retorno às tradições que não é um retorno às maneiras de fazer o antigo, com artesãos qualificados, mas simplesmente às formas exteriores: "alguns se contentariam mesmo com um retorno não mais às maneiras de fazer, mas simplesmente às formas, às aparências exteriores, pitorescas e características de construções selecionadas num passado mais ou menos longínquo (...). Baseada nesta interpretação equivocada da palavra Tradição, essa tendência nos parece tão infundada quanto de reformar a organização da profissão e o modo de produção do construído, etc. E haveria ainda os que tentariam fazer do "pós-modernismo" em arquitetura um "neo-academicismo", uma vez que "criar", no antigo sistema artístico acadêmico, consistia em ter domínio técnico para seguir uma série de regras e convenções e, sobretudo, voltar-se para o passado. Léon Krier e, novamente, Maurice Culot formariam a dupla que, retomando os ensinamentos de Quatremère de Quincy, guardião da doutrina da Academia de Belas Artes e secretário perpétuo da Instituição, reeditou De l'imitation, um tratado em prol da arquitetura clássica e contrário à inovação e ao "fetichismo do progresso". Imbuídos de passadismo e elitismo, ambos teriam integrado a "vanguarda internacional pós-moderna" e se empenhado em dar cursos sobre tijolo e pedra como elementos fundamentais das construções, estimulando os alunos a visitarem artesãos e centrando o programa no desenho, como se os arquitetos jamais tivessem deixado os ateliês do sistema Beaux-Arts.

Com efeito, a Introdução de Leon Krier à reedição de De l'imitation (1823) não deixa dúvidas sobre o seu "neo-academicismo" e sua fidelidade às causas de Quatremère de Quincy, que teria condenado a "febre da inovação" e previsto que as culturas milenares seriam reduzidas a mercadorias e os conhecimentos lançados "no mundo canibal do comércio". Certo de que os "prazeres do espírito" estão em risco na era das máquinas, o arquiteto e teórico da arquitetura empreende, em Quelles conclusions doiton tirer de la mort des arts et de l'architecture? (1980), uma veemente denúncia da universalização dos valores burgueses que teria enredado toda a sociedade num processo de consumo cultural agonizante e definitivo, destruído tanto as culturas aristocráticas quanto as populares, sacramentado a fragmentação do trabalho que separa a atividade manual da intelectual ("alienando irrevogavelmente as mãos do espírito") e levado à morte da cultura artesanal que, sendo a base de toda cultura, teria degradado o trabalho do arquiteto e gerado a destruição da inteligência humana. Enquanto forma de arte ditada pela necessidade, a arquitetura teria sido mais radicalmente inclusa nos ciclos de produção e de consumo industriais, de modo que nem o funcionalismo nem os demais movimentos de vanguarda teriam conseguido se colocar acima das leis do mercado. Nesse cenário de glorificação dos valores da maximização do lucro e acumulação do capital, o autor destaca a vitória do kitsch como o fenômeno cultural mais importante da era industrial e, não por acaso, algo que se dirige ao instinto, isto é, que não reflete, mas apenas reage, tornando-se o instrumento por meio do qual a civilização tecnológica atinge o seu ápice. Por fim, Krier postula que uma reconstrução das artes e da arquitetura exigiria uma reconstrução meticulosa do artesanato e, assim, uma resistência anti-industrial ${ }^{35}$.

Em Anachroniques d'architecture (1981) o arquiteto, professor e crítico de arquitetura francês Bernard Huet reprova os arquitetos modernistas que se consideram os detentores legítimos do cânon e os únicos a terem o direito de "excomungar os heréticos", e contraria a visão de que o historicismo pós-moderno 
seria uma regressão passadista inadaptada ao mundo moderno, já que tal movimento seria antes a mais moderna das respostas arquitetônicas, "em todo caso a mais maravilhosamente adaptada a um mundo crepuscular, fadado à permissividade, à frivolidade, à confusão e ao consumo irresponsável dos valores, dos bens, das energias e dos homens" ${ }^{\prime 36}$. Para o autor, a recorrência contemporânea ao pastiche está diretamente ligada ao que ele considera que seja - conforme visto acima - a "consternante mediocridade da arquitetura moderna" e sua incapacidade de se inserir apropriadamente num contexto histórico. Ainda que considere o pastiche como "a solução do desespero", acredita que ele seja provocante no sentido de questionar os mitos da arquitetura moderna e de revelar as falsas verdades que servem de argumento aos exegetas da modernidade. Em sua opinião, a arquitetura moderna só poderá se integrar num centro histórico antigo e se relacionar bem com as tipologias arquitetônicas englobantes e a morfologia urbana preexistente se, entre outras coisas, abandonar seus clichês (planta livre, parede de vidro, concreto, etc.l, assim como só conseguirá se comunicar melhor com os habitantes inscrevendo-se na memória coletiva e num sistema de comunicação convencional:

\begin{abstract}
A esse respeito, o que me choca, por exemplo, em Le Corbusier, é que ele fala de casa recorrendo a cinco princípios negativos que são, ponto por ponto, o inverso do que as pessoas pensam quando elas pensam em "casa". Elas pensam em "fundações", "porões", "alicerces" e ele propõe "pilotis". Elas pensam em "fachada" e ele propõe "fachada livre". Elas pensam em "paredes" e ele propõe "planta livre". Elas pensam em "telhado" e ele propõe "teto-jardim". Elas pensam em "janela" e ele propõe "janela horizontal". Por uma espécie de inversão sutil, o fundamento teórico da arquitetura moderna se situa na anti-ideia da ideia de casa $^{37}$
\end{abstract}

Quando discute a arquitetura moderna enquanto arquitetura de ruptura que acaba por empreender um efetivo rompimento com os habitantes, Huet relativiza o sentido negativo que se atribui comumente à imitação e o complementar sentido positivo que se confere à criação. Certo de que a arquitetura procede historicamente por imitação e que a arquitetura moderna de ruptura é um fenômeno recente que não representa senão uma ínfima parte da produção arquitetônica na perspectiva da longa duração, Huet acredita ser preciso restabelecer os valores da imitação, pois é por meio deles que se transmite o que foi adquirido e acumulado por milhares de anos de prática arquitetônica. Finalmente, o autor considera que, a rigor, não se pode falar em pastiche em arquitetura porque sempre é preciso integrar certo número de elementos contemporâneos que acabam por tornar a edificação completamente moderna.

$\bigcirc$ desencanto como o modernismo também figura na análise de Elizabeth Meredith Dowling em New Classicism: The Rebirth of Traditional Architecture, publicado em Nova York em 2004. O livro é dedicado aos arquitetos contemporâneos que contribuem para a expansão da linguagem clássica da arquitetura e cujas construções indicariam a renovação dos princípios clássicos no aquela, inteiramente oposta, que consistiria em querer padronizar, com base em idéias pré-concebidas, todas as construções em todos os lugares, alegando uma uniformidade teórica das necessidades do homem e dos meios industriais". Tradução nossa. No original: "quelques-uns se contenteraient même d'un retour non plus aux manières de faire, mais simplement aux formes, aux apparences extérieurs, pittoresques et caractéristiques de constructions choisies dans un passé plus ou moins éloigné (...). Basée sur cette interprétation erronée du mot Tradition, elle (cette tendance) nous semble aussi mal fondée que celle, toute contraire, qui consisterait à vouloir uniformiser de parti pris toutes les constructions en tous lieux, en arguant d'une uniformité théorique des besoins de l'homme et des moyens industriels". Cf. André Hernant, apud Monique Eleb, Soline Nivet e Jean-Louis Violeau (2005, p. 76). Para uma análise semiótica do retorno à estética passada e préindustrial do estilo regional no âmbito do mundo contemporâneo marcado pela industrialização relativa do processo de construção ver Sylvia Ostrowetsky e Jean-Samuel Bordreuil (1980).

29. Tradução nossa. No original: "c'est surtout au niveau de l'architecture extérieure que semble se situer la qualité architecturale. On aime les patios, les passerelles, les espaces plantés, la chaleur de la brique de Vaugirard". Cf. Bernard Barbe e Alain Duclent (1986, p. 97).

30. Tradução nossa. No original: "Cette architecture (extérieure) est, par contre, aux yeux de tous desservie par le béton brut, matériau dont l'aspect rebute tout le monde". Cf. Bernard Barbe e Alain Duclent (1986, p. 40). 
31. Tradução nossa. No original: "Il faut insister sur la responsabilité des architects amateurs de gros projets et bétonneurs sans tendresse". Cf. Jean-Louis Violeau (2005, p. 368).

32. Tradução nossa. No original: "le présent est laid, le passé est beau, donc l'avenir, c'est le passé". Cf. Jean-Louis Violeau (2005, p. 368).

33. Ver Jean-Louis Violeau (2005, p. 368).

34. Tradução nossa. No original: "Même médiocre, il est obligé de se situer à l'intérieur d'une hiérarchie par rapport à la rue, à la place ou au monument, alors que l'architecture dite 'moderne' s'ingénie à provoquer des ruptures qui semblent être pour certains architectes les meilleurs garants d'une originalité qui masque mal une absence de créativité profonde. Cf. JeanLouis Violeau (2005, p. 368).

35. Ver Leon Krier (1980).

36. Tradução nossa. No original: "en tout cas la plus merveilleusement adaptée à un monde crépusculaire, voué à la permissivité, à la frivolité, au confusionnisme et à la consommation irresponsable des valeurs, des biens, des énergies et des hommes". Cf. Bernard Huet (1981, p. 7).

37. Tradução nossa. No original: "A ce propos, ce qui me frappe par exemple chez Le Corbusier, c'est qu'il parle de maison à l'aide de cinq principes négatifs qui sont point par point, l'inverse de ce que les gens pensent quand ils pensent 'maison'. Ils pensent 'ancrages au sol', 'caves', 'soubassements' et il propose 'pilotis'. Ils pensent 'entrée' et il propose 'pas d'entrée'. Ils pensent 'murs' et il propose 'plan-libre'. Ils pensent 'toit' et il propose 'terrasse et jardin'. Ils pensent 'fenêtre' et il propose 'baie horizontale'. Par une espèce de desenho de casas, prédios de escritório, livrarias e, em suma, todo tipo de edifício que compõe a paisagem urbana: "Esses arquitetos acreditam que a arquitetura que se conecta com a comunidade e a memória é preferível à modernista que pretende chocar, incomodar e constantemente se reinventar" ${ }^{\prime 38}$

Insistindo no quanto a estética moderna tornou-se o cânon dominante na Academia e, portanto, na formação dos arquitetos que foram assim mais e mais privados do aprendizado e do conhecimento do design clássico, a autora discorre sobre personagens e instituições - tais como o Institute of Classical Architecture, fundado em 1991 em Nova York - unidos na contestação do modernismo e responsáveis por frearem a perda da tradição arquitetônica clássica que acompanhou durante séculos a história da humanidade. Se os arquitetos ingleses e americanos presentes no livro receberam treinamento de design clássico fora da educação arquitetônica formal em cursos aleatórios junto a professores solitários que, nas últimas décadas do século XX, transmitiram conhecimentos básicos dos princípios tradicionais, em 1989 o ensino do design clássico é reintroduzido no programa de arquitetura da University of Notre Dame, oferecendo um treinamento que não se via mais há 50 anos.

renascimento do ensino universitário dos princípios clássicos não teria sido, todavia, um retorno aos métodos antigos e sim a elaboração de um currículo moderno visando preparar os alunos para a prática contemporânea de modo a compatibilizar tópicos como sistemas estruturais modernos e conhecimento das formas construtivas tradicionais. Na Grã-Bretanha dos anos 1980, a preocupação crescente com os fracassos urbanísticos do modernismo e o impacto da arquitetura moderna nos sítios históricos tornou-se um movimento liderado pelo príncipe de Gales e que resultou numa publicação e na criação da The Prince's Foundation:

Edifícios de escala e detalhamento que respeitosamente concordam com o seu contexto histórico substituíram o anódino edifício moderno que ocupou a área devastada pela guerra em torno da Catedral St. Paul. Demonstrando ainda mais sensibilidade para com - lugar, o padrão histórico da rua medieval, como advogou John Simpson, também foi restituído. Arquitetos, artesãos e equipes de projeto urbano que trabalham em conjunto com The Prince's Foundation estão ajudando a curar a versão britânica da descontinuidade moderna ${ }^{39}$.

Na reconstituição da autora, o questionamento do modernismo fora explícito no livro do arquiteto norte-americano Robert Venturi, Complexity and Contradiction in Architecture (1966), que forneceu os fundamentos teóricos do assim chamado "pós-modernismo", contestou a ortodoxia da arquitetura moderna ("More is not less") e estimulou o interesse pela arquitetura histórica. $\bigcirc$ também famoso livro de Charles Jencks, The Language of Post-Modern Architecture (1977), teria popularizado não apenas o termo "pós-moderno", mas a insatisfação pública diante do design moderno, do mesmo modo que o movimento "New Urbanism", iniciado nos Estados Unidos, teria impulsionado a reconsideração do 
design urbanístico tradicional e, sobretudo, o respeito pelo estilo construtivo típico do contexto histórico considerado, "ao invés de expressar a ênfase modernista no contraste com o contexto circundante" 40 . Rivalizando com o Pritzker Prize, o Richard H. Driehaus Prize for Classical Architecture foi criado em 2003 para premiar as contribuições maiores no campo da arquitetura clássica e tradicional ou da preservação histórica, tendo sido Leon Krier, o "discípulo" de Quatremère de Quincy, o primeiro vencedor.

E dentre os estilos que teriam buscado ultrapassar as falhas da estética moderna dominante - em busca de uma arquitetura "intelectualmente mais complexa e estimulante emocionalmente" -, o vocabulário clássico ter-se-ia mostrado imbatível na criação de uma linguagem simbólica da ornamentação. Provocando os arquitetos modernos para os quais apenas as residências seriam desenhadas no código clássico, Dowling insiste que os clientes estariam igualmente interessados no design clássico e tradicional aplicado a museus, livrarias, edifícios comerciais e etc. Por fim, a autora assume que o século XXI seria um período eclético em termos culturais e estilísticos, de modo que os arquitetos propagadores da linguagem clássica não se furtariam ao uso dos materiais e sistemas estruturais atuais, e estariam a honrar a tripla exigência vitruviana de solidez, funcionalidade e beleza, essa última correspondendo a um valor arquitetônico atemporal que não teria sido dignificado pela arquitetura moderna.

Finalmente, a visão de que uma das manifestações evidentes da pósmodernidade é a reação à arquitetura moderna aparece em Pós-modernidade e sociedade de consumo (1985), de Fredric Jameson, para quem o "pósmodernismo" não é um termo que denomina simplesmente um novo estilo, mas que serve para correlacionar a emergência de novos traços formais na vida cultural com o surgimento de um novo tipo de vida social e uma nova ordem econômica. Certo de que o pastiche seria um dos traços mais importantes do capitalismo tardio, o professor da Duke University discute a impossibilidade de inovação estilística, a imitação de estilos mortos e o encarceramento no passado. Em trabalho posterior e de maior fôlego, o autor volta a discutir o historicismo dos arquitetos pós-modernos e, sobretudo, sua relação com a linguagem clássica e seus elementos (arquitrave, coluna, arco, ordem, verga, empena e domo), num contexto em que é a repetição e não mais a inovação radical o que está em jogo. Em Arquitetura: equivalentes espaciais no sistema mundial, capítulo do livro Pós-modernismo: a lógica cultural do capitalismo tardio (1991), Jameson problematiza o resultado paradoxal dessa arquitetura pós-moderna que funda sua pretensão à originalidade histórica justamente na renúncia à novidade, e questiona o que poderia ser original numa concepção de "neo" que adere à repetição: "Até que ponto podemos ainda descrever a originalidade da construção espacial no pós-moderno, quando este renunciou explicitamente ao grande mito modernista de produzir um espaço utópico radicalmente novo, capaz de transformar o próprio mundo?"4l. renversement subtil, le fondement théorique de l'architecture moderne se situe dans l'anti-idée de l'idée de maison". Cf. Bernard Huer (1981, p. 177).

38. Tradução nossa. No original: "These architects believe that architecture that connects with community and memory is preferable to modernist that aims to shock, disturb and constantly reinvent itself". Cf. Elisabeth Meredith Dowling (2004, p. 10).

39. Tradução nossa. No original: "Buildings of a scale and detailing that respectfully defer to their historic context have replaced the nondescript modern building that filled in the wardamaged area around St. Paul's Cathedral. Demonstrating even greater sensitivity to place, the historic medieval street pattern, as advocated by John Simpson, has also been reinstituted. The architects, craftspeople, and urban design teams working in concert with The Prince's Foundation are helping heal the British version of modern discontinuity". Cf. Elisabeth Meredith Dowling (2004, p. 23).

40. Tradução nossa. No original: "rather than expressing the modernist emphasis on contrast with the surrounding context". Cf. Elisabeth Meredith Dowling (2004, p. 23).

41. Cf. Fredric Jameson (1996, p. 125). 
42. Tradução nossa. No original: "satisfaite de retrouver là des éléments architecturaux, certes traités en béton architectonique et hors de leur échelle traditionnelle, mais marqués par l'Histoire (corniches, pilastres, frontons, etc.)". Cf. Véronique Biau (2000, p. 302).

43. Ver Ernst Hans Gombrich (2003).
Passadismo arquitetônico, vigor dos hábitos perceptivos e fabricação das tradições

Como vimos até aqui, os estudos sobre as manifestações contemporâneas de historicismo que levaram em conta o público da arquitetura apontam para certo descompasso entre a crítica erudita que se empenha em denunciar a arquitetura adulterada que depreende das construções inscritas no rótulo do "neo" e a opinião dos moradores que se sentem muitas vezes lisonjeados por habitar tais edifícios. Ao discorrer sobre a consagração pública dos arquitetos da França contemporânea, Véronique Biau discute a notoriedade de Ricardo Bofill, partidário do monumental e da expressão neoclássica em suas últimas realizações que, embora esteja longe de angariar grande reconhecimento junto aos seus pares, conta com a acolhida de uma parte do grande público "satisfeita de encontrar os elementos arquitetônicos que, mesmo construídos em concreto e fora de sua escala tradicional, são marcados pela História (cornija, pilastras, frontões, etc. ${ }^{\prime \prime 42}$. Segundo a arquiteta francesa, uma sondagem feita em 1992 para avaliar a imagem da arquitetura junto ao público francês mostrou que Bofill é o segundo arquiteto mais citado numa amostra nacional representativa de 1000 pessoas, ficando atrás somente de Le Corbusier.

Essa afeição indiscriminada do público pelos elementos arquitetônicos "marcados pela História" e que, bem ou mal, evocam o vocabulário do classicismo nos remete ao trabalho de Ernst Gombrich sobre o vigor dos hábitos perceptivos ${ }^{43}$. Tendo tratado da tendência de integração do novo ao antigo no que tange às técnicas decorativas, o historiador da arte austríaco argumenta que a necessidade de repetição domina a decoração através dos tempos e que essa "força do hábito" - para usar o título do trabalho - advém do senso de ordem: quando tudo está em movimento e não se consegue prever nada, o hábito fornece um quadro de referência para a experiência e se exprime em nossa grande facilidade de integrar o que nos é familiar. Retomando Arte e ilusão (publicado em 1960), Gombrich sustenta que a arte e o artifício têm as mesmas origens psicológicas e que na cultura é especialmente ao artifício que se recorre para resistir à mudança e perpetuar o presente. De acordo com o autor, quando as coisas começam a se perder os artesãos criam as substituições que irão perdurar: as barbas artificiais dos faraós egípcios, as perucas dos nobres ou os dentes artificiais testemunhariam o desejo de vencer a natureza ou fazer melhor do que ela. Assim como o motivo floral suplanta a flor efêmera, as cortinas pintadas duram mais que as verdadeiras. Já a sedentária civilização neolítica pintava seus muros de modo a imitar tapetes, do mesmo modo que as pinturas rupestres do antigo Egito apresentavam o motivo e a imitação de tapeçarias. A convenção de imitar uma tapeçaria por meio da pintura seria, aliás, procedimento dos mais correntes que pode ser visto em muitas igrejas medievais e mesmo na Capela Sistina.

Discutindo a crítica dos designers modernos que chamariam de "mímica" esse gênero de imitação (o linóleo que imita um azulejo de banheiro ou o papel pintado que imita a madeira), o autor precisa que a origem dessa rejeição data 
da Revolução Industrial, quando a máquina passou a poder simular o trabalho manual e o material, ambos custosos, ameaçando as tradições estabelecidas e as hierarquias dos artesanatos. Apesar de concordar parcialmente com o diagnóstico dos que condenam a imitação em nome da honestidade, ele reivindica outra avaliação desse fenômeno que para ele testemunharia antes de tudo a força do hábito: se os primeiros vagões de trem imitavam as carruagens e as primeiras lâmpadas a gás os candelabros, é porque tais imitações podiam ajudar na adaptação aos novos materiais e às novas condições, fornecendo o elemento de continuidade de que necessitaríamos. Ao invés de criticar o homem que se recusou a mudar de hábito a despeito das inovações tecnológicas, deveríamos considerar a força que emana dessa capacidade de ajustar o novo ao antigo.

A leitura que faz do célebre livro de Sir John Summerson, The Classical Language of Architecture (1963), confirmaria sua premissa do vigor dos hábitos perceptivos. Assim é que ele sublinha que, para Summerson, a tradição clássica é o tipo de concepção gráfica mais estável e exaustivo que o mundo já conheceu, tendo por isso assumido o papel de equivalente arquitetônico da língua latina. E aí também os exemplos de "imitação" seriam abundantes: Vitrúvio teria interpretado os traços proeminentes da ordem dórica a partir de formas usadas originalmente na arquitetura de madeira primitiva, o que implica dizer que as origens da tradição arquitetônica clássica residiriam na "imitação", ainda que neste caso tenha sido um material mais caro e de maior durabilidade - o mármore - que serviu à imitação da estrutura de madeira tradicional. E nesse processo de persistência das tradições os desvios deliberados seriam correntes: Michelangelo, por exemplo, teria se afastado das proporções, ordens e regras herdadas de Vitrúvio e da Antiguidade e assim por diante. Mesmo pressupondo uma coerência com relação à linguagem convencional, sempre teria havido certa liberdade de tom e mesmo soluções extravagantes: "A flexibilidade dessa linguagem, sua faculdade de adaptação colocam um problema de estética e de psicologia social que nos surpreenderia se não tivéssemos sido levados a considerá-la como evidente" 44 .

Atento aos limites de toda explicação de ordem puramente técnica, o autor insiste que a linguagem clássica teria sido adotada pelos construtores como algo evidente, disseminada em arquitetura desde o trabalho estrutural à marcenaria: todas as formas de decoração que seguem utilizando elementos originalmente destinados às estruturas de madeira dos templos gregos testemunhariam a força do hábito. $O$ interior de uma casa construída antes da revolução funcionalista do século XX tinha nas molduras das portas, bordas das mesas ou nas cornijas dos tetos a recuperação de uma forma gráfica de mais de dois mil e quinhentos anos:

O melhor exemplo que eu conheço dessa ligação entre conservadorismo e hábito perceptivo é a reação hostil com a qual o público vienense acolheu a primeira fachada de prédio funcionalista, construída por Adolf Loos. Apelidaram-na "a casa sem sobrancelhas", pois suas janelas não continham nem a cornija nem as empenas tradicionais das janelas vienenses, qualquer que fosse o seu estilo45.
44. Cf. Ernst Hans Gombrich (2003, p. 232). Tradução nossa da edição em língua francesa a que tivemos acesso.

45. Cf. Ernst Hans Gombrich (2003, p. 234). Tradução nossa da edição em língua francesa a que tivemos acesso. 
46. Tradução nossa. No original: "Whereas history was a nightmare from which the Modernists tried to awaken, it provides visions Post-Modernists attempt to recapture. Those practitioners who have been found guilty of the "crime of ornament" have been paroled in a new architectural language derived from diverse historic idioms (...) Postmodernist architects and critics find historic styles exciting because they have alerted them to the value of vernacular traditions, regional associations, and aesthetic eclecticism". Cf. Charles Dellheim (1982, p. $\mathrm{XV})$.

47. Tradução nossa. No original: "the longing for continuity without impeding the march of improvement". Cf. Charles Dellheim (1982, p. I).
Se, como visto acima, o historicismo "pós-moderno" opõe-se à arquitetura moderna que o precede, o historicismo de fins do século XIX testemunharia a tendência de integração do novo ao antigo e o intuito de criação de uma tradição num contexto de intensas mudanças sociais. Em The Face Of The Past: The Preservation Of The Medieval Inheritance In Victorian England (1982), Charles Dellheim discute o historicismo arquitetônico inglês não do ponto de vida de uma história da arquitetura atenta aos aspectos estilísticos e técnicos das construções, mas a partir dos valores e atitudes culturais dos vitorianos que experimentavam 0 paradoxo de viver na primeira nação industrializada do mundo que, no entanto, exprimia uma crescente fascinação pelo seu passado pré-industrial e especialmente por sua herança medieval. Na opinião do historiador nova-iorquino e professor da Universidade de Boston, a chamada arquitetura "pós-moderna" testemunharia a veneração contemporânea do passado:

Enquanto a história foi um pesadelo do qual os modernistas tentaram acordar, ela forneceu visões que os pós-modernistas tentaram recapturar. Aqueles profissionais que foram considerados culpados do "crime do ornamento" têm sido colocados em liberdade condicional em uma nova linguagem arquitetônica derivada de diversos idiomas históricos (...). Arquitetos e críticos pós-modernistas consideram os estilos históricos estimulantes porque eles os alertaram sobre o valor das tradições vernaculares, das associações regionais e do ecletismo estético ${ }^{46}$.

Ainda que Dellheim esteja tratando do final do século XIX, sua análise é útil para pensar a arquitetura passadista na contemporaneidade, pois mesmo naquele contexło a recorrência a uma linguagem histórica não implicou uma recusa da modernidade. Ao discutir a fachada medievalizante da moderna estação de trem londrina St. Pancras, ele sugere que a busca de progresso tecnológico e a reabilitação de formas históricas eram duas faces da mesma moeda, satisfazendo "o desejo de continuidade sem impedir a marcha do progresso"47. Questionando a perspectiva de E.P.Thompson, para quem o medievalismo inglês oitocentista seria uma atitude de protesto contra os valores e atitudes instaurados pela nova realidade capitalista e industrial, Dellheim insiste que não é possível subestimar o fato de que os artefatos medievais foram acolhidos por muitos vitorianos que não estavam em revolta contra a civilização moderna. Alfred Waterhouse, por exemplo, um dos arquitetos mais associados ao reavivamento da arquitetura gótica, soube satisfazer ao desejo público pelas fachadas pitorescas, mas sem descuidar do emprego da tecnologia a mais sofisticada para o período, compatibilizando historicismo nas formas e pragmatismo nas funções. Para Dellheim, foi justamente essa habilidade em conceber silhuetas medievais adaptáveis aos requisitos funcionais modernos que the rendeu o primeiro lugar no concurso de projetos para o novo Town Hall de Manchester em 1867.

Nesta cidade, aliás, as construções erigidas entre 1860 e 1890 em estilo neogótico, com seus adornos e fisionomias pitorescas, cumpriram a função de fazer um contraponto a uma paisagem urbana cujo utilitarismo industrial havia 
destruído a natureza e as belas paisagens, atribuindo aos seus moradores a desconfortável imagem de filistinos materialistas. Mas tal reabilitação de uma arquitetura passadista não conflitou diretamente com o progresso da modernização, isto é, os símbolos tradicionais apropriados pelos liberais em nada entravaram o livre curso do mundo dos negócios. Nessa linha de pensamento, o historiador norte-americano destaca que forças progressistas também evocaram o medievalismo, e, ainda que não necessariamente mais do que as correntes conservadoras, o fato é que os liberais também voltaram à tradição para justificar (e não invalidar) reformas, isto é, para fabricar uma tradição política viável: "A busca de pedigrees respeitáveis era uma característica comum do estilo cultural vitoriano. Tanto os liberais quanto os conservadores legitimaram suas causas evocando símbolos medievais (...). Seu medievalismo era, portanto, essencialmente moderno, no sentido de que estava preocupado com os dilemas contemporâneos" ${ }^{48}$.

A reabilitação da arquitetura gótica em Manchester, cidade historicamente associada à Revolução Industrial, evidencia o quanto as iniciativas de criação de uma "antiguidade" por meio da arquitetura se deram justamente num período de crise e de perda de poder em relação à autoridade central de Londres: num momento em que a autonomia manchesteriana estava em risco, a principal função desse imaginário era legitimar o ameaçado poder local, atestando suas raízes antigas e, portanto, seu direito ao autogoverno. A necessidade de firmar uma identidade numa conjuntura adversa deu-se exemplarmente a ver tanto na fisionomia neogótica do Town Hall quanto na iconografia de seus murais internos que celebravam os valores do progresso e do liberalismo, mas mediante roupagens históricas, glorificando a trajetória passada da capital de Lancashire. Por fim, Dellheim segue nessa interpretação de "invenção das tradições" quando aponta que em 1900 a fisionomia "medieval" da capital inglesa era mais evidente do que em períodos anteriores: "O que é mais significativo sobre esse percurso é que ele demonstra que a fisionomia da cidade era mais 'medieval' em 1900 do que tinha sido em qualquer outro momento desde 1666. Onde os restos do passado tinham em grande parte desaparecido, os vitorianos resolutamente fabricaram substitutos arquitetônicos"49.

A combinação de historicismo nas formas e pragmatismo nas funções, a criação de uma "antiguidade" por meio da arquitetura e a exaltação de valores liberais em vestes históricas foram correntes na Europa da passagem para o século XX. Ao discutir as "anomalias" que acompanharam as iniciativas de Otto Wagner no sentido de assimilar os novos materiais construtivos em seus próprios termos e não apenas dentro da tradicional gramática de expressão arquitetônica, Carl Schorske conclui, em Fin-de-Siècle Vienna: Politics and Culture (1961), que salvo exceções, os esforços do arquiteto foram marcados pela dissonância entre uma ética de construção funcional e uma tradição estética de embelezamento. Mesmo na construção de viadutos e pontes em que pôde atuar mais radicalmente atribuindo primazia a questões de engenharia estrutural, "ainda aí, Wagner geralmente harmonizou sua estética estrutural radical com a tradição, acrescentando
48. Tradução nossa. No original: "The search for respectable pedigrees was a common feature of the Victorian cultural style. Liberals and conservatives alike legitimized their causes by invoking medieval symbols [...] Their medievalism, therefore, was essentially modern in the sense that it was concerned with contemporary dilemmas". Cf. Charles Dellheim (1982, p. 18).

49. Tradução nossa. No original: "What is most significant about this route is that it demonstrates that the face of the city was more 'medieval' in 1900 than it had been at any time since 1666. Where the remnants of the past had largely vanished, the Victorians resolutely manufactured architectural surrogates". Cf. Charles Dellheim (1982, p. 10). 
50. Tradução da edição brasileira de 1988 (p. 97). No original: "yet even here Wagner usually tuned his radical structural aesthetic to tradition by adding cosmetically the features that would make the structure beautiful: stone facings to screen raw iron pillars; swags, wreaths, and statuary to adorn and, as it were, to civilize the new structural material”. Cf. Carl Schorske (1981, p. 81).

51. Tradução da edição brasileira de 1988 (p. 54). No original: "In Austria as elsewhere, the triumphant middle class was assertive in its independence of the past in law and science. But whenever it strove to express its values in architecture, it retreated into history". Cf. Carl Schorske (1981, p. 36).

52. Tradução da edição brasileira de 1988 (p. 61). No original: "Where historical tradition was lacking, historical erudition had thus to fill the void". Cf. Carl Schorske (1981, p. 43).

53. Tradução da edição brasileira de 1988 (p. 63). No original: "the truth of industrial and commercial society had to be screened in the decent draperies of pre-industrial artistic styles. Science and law were modern truth, but beauty came from history". Cf. Carl Schorske (1981, p. 45). cosmeticamente os traços que embelezariam a estrutura: revestimentos de pedra para encobrir pilares de ferro nu, festões, grinaldas e esculturas para adornar e, por assim dizer, civilizar o novo material estrutural" 50 . Para o historiador da Princeton University, os liberais austríacos que adquiriram poder econômico e político na segunda metade do século XIX foram pouco ousados culturalmente: "Na Áustria, como em outros lugares, a classe média triunfante foi peremptória em sua independência do passado, quanto ao direito e à ciência. Mas sempre que lutou para expressar seus valores na arquitetura, ela retrocedeu para a história"51. $\bigcirc$ exame da remodelação de Viena encabeçada por esses liberais recém-chegados ao poder mostrou como o historicismo arquitetônico associou-se intimamente à falta de ancoragem real no passado por parte desses grupos emergentes: "Onde faltava tradição histórica, a erudição histórica teria então de preencher o vazio" ${ }^{52}$. $\mathrm{Na}$ Ringstrasse, o centro dessa reconstrução urbana, prevaleceu a ênfase nas funções de representação, já que seus prédios monumentais construídos em vários estilos históricos evidenciavam que "a verdade da sociedade industrial e comercial tinha de ser envolta nos tecidos decorosos dos estilos artísticos pré-industriais"53.

Em A força da tradição: a persistência do antigo regime (1990 [1983]), Arno Mayer também fala de uma burguesia economicamente moderna, mas culturalmente submissa. Tendo notado o gosto passadista dos burgueses europeus que, entre 1848 e 1914, investiam nos valores consagrados da arte "clássica" ao invés de apoiarem os feitos modernistas, o historiador de origem luxemburguesa afirma que a arquitetura, tida como o espelho mais exemplar de uma cultura, revelou nesse período um historicismo intransigente. Mesmo nas grandes cidades que conheceram um rápido crescimento econômico foram construídos edifícios públicos numa gama de estilos históricos puros ou misturados de maneira eclética. Em lugar de um estilo próprio à sociedade nascente, ocorria mesmo de as construções combinarem dois ou três estilos antigos (grego, romano, bizantino, gótico, renascentista, barrocol, de modo que cidades em plena expansão e mudança conservavam ou adquiriam um aspecto pré-moderno.

Em Paris XIXe siècle: I'immeuble et la rue (1987), François Loyer acompanha o vaivém das alternâncias entre o partido da ornamentação e o do despojamento na arquitetura parisiense oitocentista e vê o historicismo como estratégia de distinção vigente nas relações de classe. Se o "triunfo do ornamento" na arquitetura dos últimos anos do reinado de Luís Felipe, com seus arabescos de ferro nas sacadas e seus jogos de pilastras, contribuiu para que a riqueza ornamental se tornasse símbolo manifesto de um estatuto social privilegiado, as radicais mudanças técnicas introduzidas pelos processos industriais de reprodução atenuaram a equivalência entre a riqueza do ornamento e a própria riqueza. Quando os moldes decorativos passam a ser produzidos industrialmente, tornando a exuberância na decoração acessível à pequena burguesia, não será mais o ornamento em si o elemento decisivo de distinção social, mas a originalidade do mesmo. E nesse contexto de reprodução em série dos artifícios de embelezamento, o recurso aos estilos históricos torna-se uma 
ferramenta central de busca de originalidade decorativa e, por meio dela, de manutenção da hierarquia social:

Desse ponto de vista, pode ser considerado significativo o recurso aos estilos históricos, porque este permite ampliar o escopo dos repertórios decorativos e descobrir um grande número de combinações novas, originais, entre os elementos desses repertórios. 0 ecletismo admite assim uma parte de suas raízes sociológicas: seu sistema de invenção ornamental é o reflexo de uma sútil hierarquia de classes - e dos meios de mantê-la, através das transgressões de que ela é vítima sob a pressão das classes médias ávidas de reconhecimento social la abordagem balzaquiana do mundo parisiense prova a realidade deste último problema) ${ }^{54}$.

mundo da produção arquitetônica contemporânea como campo

Passadismo arquitetônico e fabricação industrial de uma arquitetura de aparência tradicional também foram temas discutidos por Pierre Bourdieu em Les structures sociales de l'économie (2000), estudo voltado ao mercado imobiliário francês e, mais especificamente, à produção e comercialização de casas individuais. Tendo como objetivo mais amplo contradizer as teorias econômicas que, imbuídas de um preconceito escolástico desistoricizado e desistoricizante, apostam num agente econômico calculista e movido por interesses estritamente racionais, o autor insistirá que toda e qualquer prática econômica não tem nada de evidente e universal e, por conta disso, as análises das atitudes concernentes ao jogo econômico devem obrigatoriamente levar em conta todos os condicionantes subjacentes a tais condutas. Nessa linha de juízo, o estudo da produção e comercialização de residências a partir do instrumental das ciências sociais deve considerar as disposições dos agentes, seus meios econômicos e seus gostos, mas, também, o estado da oferta da habitação e as formas de ajuda financeira (empréstimos, exonerações, créditos) disponíveis aos construtores e aos compradores e que também favorecem as "escolhas" em matéria de moradia. Para o sociólogo francês, o Estado tem um papel decisivo no mercado imobiliário, seja por meio da produção da demanda e, portanto, dos sistemas de preferências individuais, seja mediante a distribuição dos recursos necessários à construção e à habitação definidas pelas leis e normas arquitetônicas.

De saída, a análise das disposições dos agentes e da estrutura do campo de produção de imóveis destaca o quanto a casa é um produto cujo componente simbólico é especialmente forte. Propriedade que exprime de maneira decisiva o ser social de seu possuidor, seus meios econômicos e seus gostos, um imóvel não se define completamente senão na relação entre suas características objetivas (tanto técnicas quanto formais) e os esquemas inseparavelmente éticos e estéticos dos habitus que estruturam a percepção e a apreciação que se tem dele, e que desse modo definirão a demanda real com a qual os produtores deverão contar. Longe de ser apenas um investimento econômico, a compra de uma casa, que envolve uma das decisões mais difíceis e prenhes de consequências durante
54. Tradução nossa. No original: "De ce point de vue, on peut considérer comme significatif le recours aux styles historiques, parce que celui-ci permet l'élargissement du champ des répertoires décoratifs et la découverte d'un très grand nombre de combinaisons nouvelles, originales, entre les éléments de ces répertoires. L'éclectisme avoue ainsi une part de ses sources sociologiques : son système d'invention ornementale est le reflet d'une subtile hiérarchie de classes - et des moyens de maintenir celle-ci, à travers les transgressions dont elle est victime sous la poussée des classes moyennes, avides de reconnaissance sociale (l'approche balzacienne du monde parisien prouve la réalité de ce dernier problème)". Cf. François Loyer (1987, p.150-151). 
55. Tradução nossa. No original: "L'effet symbolique de l'annonce est le produit d'une collaboration entre l'auteur, qui puise dans son patrimoine culturel des mots et des images capables de réveiller chez son lecteur des expériences uniques, et le lecteur, qui contribue à conférer au texte inducteur le pouvoir symbolique ou, mieux, le charme qu'il exerce sur lui : fort de toutes ses expériences antérieurs du monde ordinaire et aussi du monde littéraire, ce dernier projette sur le texte-prétexte l'aura de correspondances, de résonances et d'analogies qui lui permettent de se reconnaître en lui ; et c'est parce qu'il se retrouve, comme on dit, dans la petite mythologie privée du monde domestique qui lui est proposée qu'il peut la faire sienne, se l'approprier en se laissant posséder par elle". Cf. Pierre Bourdieu (2000, p. 39).

56. Tradução nossa. No original: "On sait en outre que la propension à attacher plus d'importance à l'aspect technique et moins à l'aspect symbolique de la maison croît à mesure que l'on descend dans la hiérarchie sociale". Cf. Pierre Bourdieu (2000, p. 47). o ciclo de uma vida, é também uma aposta afetiva envolta em toda a herança de mitologias coletivas associadas à residência, cujo significado e função variam e se especificam segundo a posição social e o contexto histórico.

Um dos valores tratados pelo autor - e constantemente evocado e reativado pela retórica publicitária - reside na preferência pelo antigo e pelo tradicional, mesmo que sob a forma da imitação grosseira. Assim, se é inegável que a produção produz o consumidor, isto é, se pelo simples fato de anular as outras maneiras possíveis de satisfazer à necessidade de habitar, a oferta produz o comprador, impondo um modo específico de satisfazer a essa necessidade sob a aparência de respeitar o gosto do freguês, também não é menos certo que arquitetos, engenheiros, promotores e demais agentes dotados do poder social de construir adaptam suas práticas às estruturas de percepção coletivas e, nesse sentido, a publicidade dos anúncios imobiliários, encarregada de transmutar um simples objeto técnico numa espécie de artefato sagrado, será tanto mais eficaz quanto mais conseguir honrar as disposições pré-existentes da clientela. No contexto francês discutido pelo autor, as construtoras que conseguem organizar a sua produção de modo a dar a uma fabricação industrial a aparência de uma confecção de tipo tradicional só serão bem sucedidas se conseguirem fazer com que as pessoas paguem caro por esse desejo de habitar uma casa dita artesanal, supostamente construída à moda antiga. Tendo em vista que a decisão de compra envolve a um só tempo o estado da oferta proposto num dado momento pelo campo da produção, mas, também, as exigências inscritas nas disposições dos eventuais compradores, pode-se dizer que estes também conseguem impor o que deve ser a definição dominante do produto:

efeito simbólico do anúncio é o produto de uma colaboração entre o autor, que extrai do seu patrimônio cultural palavras e imagens capazes de despertar no seu leitor experiências únicas, e o leitor, que contribui para conferir ao texto indutor o poder simbólico ou, melhor, o charme que ele exerce sobre ele: prenhe de todas as suas experiências anteriores do mundo ordinário e também do mundo literário, este último projeta sobre o texto-pretexto a aura de correspondências, ressonâncias e analogias que The permitem se reconhecer nele; e é porque ele se encontra, como se diz, na pequena mitologia privada do mundo doméstico que the é proposta que ele pode fazer dela a sua própria, apropriando-se dela e deixando-se possuir por ela ${ }^{55}$.

Ao analisar o espaço dos compradores e a gênese social dos gostos, Bourdieu insiste que, em matéria de casa como alhures, as expectativas não são universais, mas diferenciadas segundo a posição ocupada no espaço social: o capital econômico, o capital cultural, a estrutura do volume total de capital e sua evolução no tempo, a idade, o estatuto matrimonial, o número de filhos e a posição no ciclo de vida são todos fatores determinantes do sistema de preferências: "É sabido que a propensão a atribuir mais importância ao aspecto técnico e menos ao aspecto simbólico da casa aumenta à medida que se desce na hierarquia social"56. Quando atenta para as representações da casa pré-fabricada, por 
exemplo, ele nota que enquanto as classes sociais mais dotadas de capital econômico e cultural têm uma visão negativa desse tipo de empreendimento, os grupos mais desfavorecidos, mais tendentes a aderir a uma estética funcionalista ${ }^{57}$, são mais frequentemente capazes de enxergar boas razões para se escolher morar nesse tipo de imóvel.

Nesse trabalho publicado em 2000, o professor do Collège de France insiste que a análise da lógica do mercado de casas individuais não pode prescindir da investigação das relações objetivas que se estabelecem entre os diferentes construtores em concorrência pela conquista de partes do mercado. Considerar a produção e a circulação desse bem econômico e simbólico em termos de um campo de forças cuja estrutura, num dado momento, está no princípio das lutas visando conservá-lo ou transformá-lo, permite, na opinião do autor, levar em conta as diferenças entre as empresas e as relações objetivas de complementariedade na rivalidade que as opõem e as unem ao mesmo tempo. E permite ainda compreender a lógica da concorrência e determinar quais são os trunfos específicos responsáveis por atribuir a cada uma das construtoras uma dada posição no espaço do campo. Se todo campo tem leis gerais que funcionam para todos os outros, as mesmas se especificam em função das qualidades características do produto que está em jogo; no caso em pauta, as propriedades que fazem da residência um bem inteiramente singular (e que, portanto, explicam as características particulares desse campo de produção) dizem respeito ao fato dela ser dotada de uma forte carga simbólica e de manter uma relação crucial com o espaço. Devido à sua dimensão simbólica, a produção de casas se encontra a meio caminho entre duas formas opostas de atividade produtiva: de um lado, a produção de obras de arte e, de outro, a produção de bens materiais. No primeiro caso, a parte objetivamente consagrada à promoção-criação simbólica é muito mais importante do que a dedicada à fabricação do produto material, enquanto que no segundo caso, ou seja, na produção de bens materiais, tem-se a situação exatamente inversa.

A partir de indicadores como a estrutura de empregos de cada uma das construtoras (peso relativo de operários, artesãos, engenheiros, publicitários, executivos, especialistas do mercado financeirol, dados cruciais na determinação de sua orientação, o autor conclui que as empresas que dominam o mercado são as mais bem sucedidas na fabricação industrial de produtos de aparência tradicional, isto é, na produção industrial de imóveis cuja roupagem externa ostenta um aspecto de artesanato tradicional. Investindo fortemente em publicidade, intimamente ligadas ao mercado financeiro e recorrendo ao trabalho terceirizado, tais construtoras logram conferir à fabricação industrial de sua produção em série ares de um artesanato tradicional. E num domínio em que a arte de produzir aparências é tão importante, não é estranho supor que essas grandes construtoras que dominam o mercado produzindo industrialmente casas de aspecto tradicional acabam por se sobrepor às empresas menores que realmente produzem de maneira tradicional, ainda que de modo mais ou menos adulterado 58 .
57. Cabe precisar que o autor não fala de "estética funcionalista" no sentido dos princípios do modernismo arquitetônico que pregam que a forma deve seguir a função. Nas várias obras em que Bourdieu discute o gosto de um ponto de vista sociológico, ele aponta para as preferências "funcionalistas" das classes populares, no sentido de um privilegiamento do conteúdo e da função em detrimento da forma, ou do objeto representado em detrimento do modo de representação do objeto, ou seja, no sentido de se opor inteiramente ao que Max weber chamou de "estilização da vida", o que em termos bourdieusianos consiste em deslocar a ênfase da "matéria" em direção da "maneira" (de apresentar e de se servir dos objetos os mais ordinários), lançando uma olhar propriamente estético não apenas sobre as obras de arte, mas também sobre todas as coisas do mundo. Ver, a esse respeito, Pierre Bourdieu (1979).

58. Dito isso, o autor insiste que tais empresas artesanais são indispensáveis ao funcionamento de todo o sistema, na medida em que the fornecem sua justificação simbólica: "Por meio das "casas burguesas" que elas executam frequentemente num estilo local que é o produto de uma reconstrução histórica mais ou menos aproximativa - residências senhoriais, mansões, etc. -, elas continuam a dar vida e concretude ao modelo dominante de casa tradicional que tantos compradores carregam no seu inconsciente como uma sorte de ideal, e isso para além dos limites da clientela capaz de adquiri-la". "À travers les 'maisons bourgeoises' qu'elles exécutent souvent dans un style local qui est le produit 
d'une reconstitution historique plus ou moins approximative - manoirs, demeures, etc. -, elles continuent à donner vie et figure concrète, au modèle dominant de la maison traditionnelle que tant d'acheteurs portent dans leur inconsciente comme une sorte d'idéal, et cela bien au-delà des limites de la clientèle capable de se l'offrir" Cf. Pierre Bourdieu (2000, p. 75-76).

59. O prestígio do antigo e do tradicional também aparece no estudo de Lise Bernard sobre os corretores imobiliários franceses. Quando discute o caso de um corretor novo no métier e as astúcias linguísticas que lhe parecem as mais convincentes durante as visitas aos imóveis junto aos eventuais compradores, a autora destaca a expressão "charme de l'ancien", que ele ouvira várias vezes pronunciada por colegas mais experientes e que passara a repetir com sucesso junto aos clientes. Cf. Lise Bernard (2012).
Para Bourdieu, tudo era relativamente claro enquanto a distribuição de trunfos técnicos variou em razão inversa da distribuição de trunfos simbólicos, isto é, enquanto existiam, de um lado, empresas dotadas de um nível mais alto de industrialização e, de outro, as que atuavam segundo o modo de produção artesanal. Tal equilíbrio teria se rompido a partir de uma inovação organizacional que permitiu que algumas empresas de construção passassem a produzir industrialmente o falso tradicional, notadamente por meio da conversão de uma particularidade de sua organização - como o recurso massivo à terceirização e à franquia - em partido simbólico, logrando assim conciliar o inconciliável, isto é, acumular as vantagens técnicas da produção em série e os benefícios simbólicos da produção artesanal.

A contradição entre os procedimentos de fabricação industrial e as expectativas da clientela afeita ao tradicional será cuidadosamente levada em conta pela retórica publicitária, que será tanto mais importante quanto mais poderosa for a construtora e tanto mais eficaz quanto mais conseguir honrar as disposições pré-existentes do público visado. Recorrer à publicidade imobiliária significa, para as construtoras, todo um trabalho feito para aproximar o imóvel oferecido do imóvel esperado, mas, também, trabalhar para transformar os esquemas de percepção e de apreciação socialmente constituídos (os gostos) que os potenciais compradores aplicarão aos seus produtos, à sua realidade física, ao material de que é feito e ao seu modo de fabricação. Desse modo, os procedimentos retóricos empregados pelos publicitários sublinharão as vantagens do que é proposto e mascararão os seus inconvenientes a fim de desarmar eventuais resistências. Procurando minorar a distância entre o imóvel oferecido e as áreas centrais da cidade ou o local de trabalho, por exemplo, convidarão o comprador a fazer da necessidade virtude ao converter a periferia longínqua em retorno eletivo à vida campestre. Tais procedimentos retóricos mudam conforme a posição da construtora no campo, podendo em alguns casos acentuar as qualidades técnicas do produto e, em outros, fundar sua estratégia de convencimento na produção das aparências de um produto e, no caso em pauta, em seu modo de fabricação supostamente tradicional. Assim é que alguns construtores camuflarão os componentes industriais com fachadas puramente decorativas e com discursos baseados no prestígio do nobre, do antigo e do tradicional ${ }^{59}$.

As relações de força entre todas as construtoras dependem da conjuntura econômica global, que elas refratam segundo sua lógica específica. E é justamente na conjuntura de uma crise, de encolhimento do mercado, que o efeito do campo se faz sentir com mais intensidade. Devendo levar em conta, em suas estratégias de fabricação e comercialização, as expectativas do tradicional e do personalizado, as grandes empresas industriais que, no entanto, só poderão baixar os custos da produção mediante a estandardização do produto, deverão multiplicar suas estratégias técnicas (diversificação de modelos), organizacionais (organização em grande escala de uma fabricação de ares tradicionais) ou simbólicas (recurso à retórica do antigo) para limitar os efeitos produzidos pela 
crise. Em tal conjuntura, os efeitos da concorrência se fazem notar, por exemplo, na propensão de uma grande empresa em oferecer produtos capazes de rivalizar com aqueles que obtêm sucesso junto aos seus adversários mais diretos. Os próprios clientes estariam a comunicar aos vendedores os argumentos propostos pelos concorrentes mais próximos, e toda essa circulação de informação pode resultar em situações extremas de plágio, aparição simultânea de modelos semelhantes e mesmo de caça aos vendedores e funcionários de uma empresa com a qual se compete. Nessas disputas em que se abocanham mutualmente ideias, procedimentos e empregados, as diferentes construtoras investirão todos os seus trunfos para se lançarem numa batalha na qual todo o passado da relação estrutural estará presente em cada lance. No caso de uma crise ocorrida nos anos 1980 no mundo da construção francesa, o autor concluiu que seu legado assegurou o triunfo de uma demanda mais tradicional do ponto de vista técnico e estético, "blocos de concreto para as paredes, vigas industriais para a estrutura, madeira para a marcenaria exterior (com as janelas em formato de pequenos quadrados estilo 'île-de-France, muito caras e pouco sólidas)"60. Outra consequência dessa crise teria sido o encolhimento do mercado, traduzido no estreitamento da dispersão social da clientela, já que as empresas que mais sofreram foram as que produziam em série por preços mais baixos. Inversamente, construtoras devotadas exclusivamente ao público abastado só sobreviveram à difícil conjuntura econômica mediante a diversificação de suas atividades produtivas a fim de atenderem grupos mais modestos.

Além da análise das construtoras no campo de construtores visto em seu conjunto, Bourdieu atenta para cada uma dessas construtoras que, ao menos no caso das maiores, seriam unidades relativamente autônomas funcionando elas próprias como campo. E nesse ponto o autor incide novamente contra o voluntarismo que vê nas orientações de uma empresa o mero reflexo das "escolhas" identificadas a uma única pessoa, a um único sujeito racional, ao invés de uma entidade cujos passos são determinados pela sua posição na estrutura do campo dos construtores e, também, por sua estrutura interna, ela própria dotada de uma história social capaz de influenciar o seu presente. Nessa linha de juízo, os agentes integrantes de seus diferentes departamentos internos (produção, pesquisa, marketing, financiamento, etc.) podem divergir sobre múltiplos assuntos e a capacidade de propor decisões que serão acolhidas por todos depende do peso de cada um e da importância dos interesses específicos que representam nas relações de força no seio da empresa. Assim, o que se chama comumente de "a política da empresa" não é senão essa estrutura da relação de força envolvendo os vários agentes que dela participam ou pelo menos os que dispõem de maior poder decisório em função da posição ocupada na corporação lque depende do volume e estrutura de seu capital). A compreensão das estratégias dessas construtoras em luta pela dominação do mercado exige, pois, que se leve em conta toda a história social da empresa e, também, a estrutura e a história do campo em que se move e que estão presentes em cada uma das decisões empresariais.
60. Tradução nossa. No original: "parpaings pour les murs, fermettes industrielles pour la charpente, bois pour les menuiseries extérieures (avec les fenêtres à petits carreaux style 'Ile-deFrance', très chères et peu solides)". Cf. Pierre Bourdieu (2000, p. 92). 
61. Tradução nossa. No original: "et qui ne peut être concevable, et surtout efficace symboliquement, que sur la base d'une affinité, garantie par l'homologie des positions, entre les habitus des acheteurs et des vendeurs". Cf. Pierre Bourdieu (2000, p. 98). O trabalho de Lise Bernard sobre os agentes imobiliários franceses também destacou que um corretor tem tanto mais chances de poder confortar um cliente e de compreender seu gosto quanto maior for a proximidade social entre ambos. Cf. Lise Bernard (2012).

62. Ver Raymonde Moulin (1973) e Jean-Pierre Martinon (1974) apud Véronique Biau (2000).

63. Ver Jacques Allégret; Régis Bertrand; Anne Debarre; Florence Accorsi (1989) apud Véronique Biau (2000).

64. Ver Weld Coxe et al. (1990) apud Véronique Biau (2000).

65. Ver Veronique Biau (2000).
Por fim, esse espaço diferenciado e estruturado que é o espaço da oferta - isto é, das empresas produtoras de casas - manteria uma relação de homologia com o espaço diferenciado e estruturado da demanda - ou seja, dos compradores. Mas aí, novamente, não existiria um cálculo racional responsável por ajustar a oferta e a demanda. Ao contrário do que se poderia pensar, não há nada de natural no fato de que os compradores mais desfavorecidos se dirigem aos imóveis mais desvantajosos, sobretudo esteticamente: se os clientes procuram as construtoras que ocupam no campo dos produtores de residências uma situação homóloga à sua posição social é porque a correspondência entre as características sociais desses clientes e as das empresas (e, portanto, de seus produtos, de seus vendedores e de sua publicidade) está no princípio de toda uma série de efeitos estratégicos essencialmente não desejados e semi-inconscientes. Contrário ao mito liberal da "mão invisível" há, para Bourdieu, uma "orquestração sem chefe de orquestra", inúmeras estratégias sem "sujeitos", uma vez que são mais inconscientes do que propriamente calculadas, como a que leva um vendedor a identificar seus interesses com aqueles de seus clientes e a apresentar-se como garantia da transação ("eu tenho esse mesmo produto"), "e que só pode ser concebível e, sobretudo, eficaz simbolicamente, com base numa afinidade garantida pela homologia de posições entre os habitus dos compradores e dos vendedores" 61 .

Outro trabalho que aborda o mundo da arquitetura contemporânea como "campo" é a tese de Véronique Biau sobre as razões de emergência das novas elites de arquitetos franceses e, portanto, sobre o próprio sistema de consagração em arquitetura. Apesar de o historicismo arquitetônico não ser o tema de La consécration en architecture: l'émergence de nouvelles élites architecturales en France (2000) ainda que aborde o sucesso de público dos feitos neoclássicos de Ricardo Bofill -, a análise da diversidade da situação profissional dos arquitetos e das várias tipologias que buscaram classificar as diferentes maneiras de exercer a profissão nos foi útil para que pudéssemos discernir, numa etapa posterior da nossa investigação que tem em vista o contexto brasileiro, a figura ideal-típica do arquiteto promotor dos edifícios denominados "neoclássicos" na São Paulo contemporânea.

"Arquitetos de negócios" segundo a terminologia de Raymonde Moulin e de Jean-Pierre Martinon62, "produtores de grande consumo" na classificação de Jacques Allégret ${ }^{63}$, "arquitetos orientados para o produto" na tipologia de autores anglo-saxões ${ }^{64}$ e, por fim, "arquitetos de negócios" e "arquitetos-artesãos" no sistema classificatório de Biau ${ }^{65}$, tais profissionais se caracterizariam, de modo geral (isto é, levando em conta o que têm em comum segundo essas várias tipologias), pelo tratamento de encomendas ordinárias de massa mediante a integração das novas condições de racionalização e de divisão do trabalho, bem como das exigências de rentabilidade dos promotores imobiliários. Integrantes da categoria mais numerosa, tais arquitetos priorizariam, na concepção de seus projetos, critérios econômicos e de conforto, seriam mais especializados nos aspectos mais pragmáticos de sua atividade, mais submetidos às lógicas técnico-econômicas da lucratividade do investimento e menos preocupados com um reconhecimento advindo 
dos meios intelectuais e artísticos. Trabalhando frequentemente em firmas grandes, tais profissionais devem se mostrar mais eficazes do que criativos na execução de suas encomendas, capazes de elaborar protótipos bem estudados técnica e funcionalmente, de modo a permitir uma produção em série. Orientados para a confecção de um produto, eles aceitam uma grande divisão do trabalho no processo de projetar e construir, à custa de certo apagamento de sua assinatura e de terem que aceitar negociar com seus clientes questões de estética e de propriedade artística.

Se dentre as preocupações profissionais desses "arquitetos de negócios", o valor atribuído à "criação", na prática da concepção, é menos pronunciado, o mesmo não ocorre com os "arquitetos-criadores", que são os menos numerosos, mas, ao mesmo tempo, os mais visíveis, e também os que fornecem a imagem a mais representativa da profissão. Do ponto de vista da história da arquitetura, o "arquitetocriador" adere à ideologia do "arquiteto-artista", por sua vez associado ao processo de desprendimento do profissional da arquitetura do ofício do construtor e do estatuto de mero executor de um trabalho mecânico, para aproximá-lo, a partir do Renascimento, do artista e do erudito capaz de conceber tratados concernentes à sua disciplina, e de legislar acerca de conhecimentos abstratos como a geometria e a estética. Historicamente, portanto, é o "arquiteto-criador" que encarna os predicados mais exclusivos da profissão, aquele que realiza as obras mais conhecidas e as mais perenes, que serve de modelo aos estudantes através do sistema de ensino da arquitetura, que é o mais celebrado pelas instâncias de reconhecimento do campo da arquitetura (revistas especializadas, concursos, prêmios e grandes exposições) e o mais tendente a dispor de um lugar futuro na história da arquitetura. De acordo com a bibliografia discutida por Biau, o arquiteto dotado desse que é o perfil mais prestigiado busca ser o mínimo possível influenciado pelos constrangimentos materiais da construção e menospreza o gosto do grande público que, pouco cultivado em arquitetura, daria muita importância a critérios como a comodidade dos espaços e o respeito dos códigos estéticos mais triviais.

A maior presença dos arquitetos-criadores na crítica de arquitetura evidenciaria como as diferentes estratégias de autopromoção correspondem às não menos diversas posições no campo da arquitetura: enquanto o principal alvo dos "arquitetos de negócios" é o cliente le a conquista de novos empreendimentos por meio do marketing), os "arquitetos-criadores" se empenham em conseguir publicações sobre suas realizações na imprensa especializada.

Além dessas duas categorias um tanto quanto extremas do "arquitetocriador" e do "arquiteto de negócios", as diferentes tipologias arroladas (que nem sempre apresentam tipos análogos, tendo em vista os diferentes critérios levados em conta e também o momento histórico em que cada categorização foi feita) tratam de posições profissionais mais intermediárias (com a dos arquitetos que prestam serviço a poucos clientes particulares) e também mais especializadas (como os dedicados à conservação dos monumentos históricos ou os que se tornam consultores da administração pública, mais ligados ao urbanismo). 
66. Dois outros fatores explicariam, segundo a autora, a permanência da tradição modernista no Brasil: o prestígio internacional da arquitetura moderna brasileira no pósguerra e a relação entre esta arquitetura e uma ideologia política de esquerda contrária à ditadura militar anticomunista.

67. "Quando aparece entre nós é o pastiche do pastiche. O Michael Graves faz um arco assim, assim, você vai a São Paulo e encontra a mesma coisa". Cf. Sylvia Ficher (2008, p. 12).

68. Cf. "Requinte da arquitetura francesa" (2002).

69. Ver Jean-Christophe Bailly (1987).

70. Se em Paris, de um modo geral, os prédios (neoclássicos ou não) foram subordinados à opção do alinhamento e da impregnação unânime das fachadas no plano do conjunto ("comme les livres d'une bibliothèque", para falar como Jean-Christophe Bailly), dispensando portarias aparatosas $\mathrm{e}$ individualizadas, tal não é o caso em São Paulo, onde não houve o intento de produzir uma solidariedade entre os imóveis. Em sua análise histórica das singularidades da urbanização paulistana, Paulo Garcez Marins (1998) mostra como as características de privacidade e isolamento dos bairros de palacetes e dos "jardins" acabaram dando o padrão da verticalização da moradia de elite de um modo geral: prédios de apartamentos com recuos laterais $\mathrm{e}$ frontais, por exemplo, que passaram a vigorar na legislação paulistana, lograram manter a separação rígida entre os espaços público e privado

\section{Considerações finais}

Todo esse debate que buscamos reconstituir tem em vista a experiência européia e norte-americana e, não, a brasileira, na qual o historicismo arquitetônico sempre teria sido, na opinião de Sylvia Ficher, menos tolerado e mais improvável. Crítica do que considera ser a hegemonia da arquitetura modernista no Brasil, a professora da Universidade de Brasília avalia, em Reflexões sobre o pós-modernismo (2008), que entre o início dos anos 1970 e meados da década de 1980 teria de fato havido um momento "pós-moderno" em arquitetura lque não necessariamente se encerra naquele período), identificado por uma vigorosa rejeição do modernismo. O caso brasileiro seria, no entanto, muito diferente, devido ao fato de que aqui a arquitetura moderna teria tido uma permanência bem mais forte, a começar do fato de que no Brasil a própria formação da profissão de arquiteto, nos anos 1930, esteve atrelada à assimilação do modernismo. A dependência da arquitetura moderna para a sedimentação da corporação dos arquitetos explicaria nossa dificuldade em abrir mão dos preceitos modernistas, assim como a orientação de nossa historiografia em que tudo seria avaliado bom ou ruim tendo como referência exclusiva a arquitetura moderna ${ }^{66}$.

Mas apesar de denunciar a presença hegemônica do modernismo nos esquemas de apreciação arquitetônica no Brasil, Ficher não deixa de concordar com a crítica de arquitetura brasileira apresentada no início deste texto, uma vez que a ela se une na desclassificação do "neoclassicismo" adulterado que prolifera em São Paulo67. Com efeito, ao fazer uma análise em termos de "pastiche do pastiche" a autora empreende, tal como os colegas aos quais se opõe, uma apreciação especialmente técnica e formal que the permite dizer que, a rigor, não podemos falar em historicismo para o caso brasileiro.

Ocorre que, como apontam muitas obras mobilizadas neste balanço, as discrepâncias entre o que existe "de fato" e o que povoa o imaginário coletivo não necessariamente impede (nem nos isenta de estudar) a produção da crença no falso tradicional, que é o que na verdade garante a legitimidade pública dessas edificações. Dito isso, e reiterando o que vimos dizendo desde o início, o deciframento da eficácia de toda e qualquer arquitetura exige uma análise que não se limite a vociferar contra a desenvoltura com que os promotores imobiliários manipulam categorias históricas como argumento de venda, como quando ostentam, em suas estratégias publicitárias, as pesquisas que uma dada construtora teria empreendido em Paris, a fim de reproduzir em São Paulo o "requinte da arquitetura francesa"68. Não basta insistir, por exemplo, que o alinhamento das fachadas que é característico da Paris oitocentista - e em boa medida mantido até os dias atuais ${ }^{69}$ - é configuração estranha à paisagem urbana paulistana, marcada pelo descaso para com a constância das alturas e o alinhamento dos edifícios, e, também, pela negligência do espaço público ${ }^{70}$. Importa menos, em suma, indagar o quanto uma arquitetura ou um "estilo" existe (se é que existe) na realidade, do 
que apreender as representações que produzem a crença nessa existência que, no entanto, pode muito bem estar presente tão-somente na imaginação ${ }^{71}$.

Do ponto de vista do debate que depreende da literatura internacional aqui passada em revista, tal orientação analítica que opera na chave da detração indignada latribuindo ou não ao modernismo o monopólio da autoridade em matéria de habitação) não parece a mais propícia à decifração exaustiva da gênese sociocultural do gosto "neoclássico" na arquitetura de São Paulo na segunda metade do século XX. A esse respeito, e considerando-se todas as correntes apresentadas, nenhuma inspiração teórico-metodológica parece mais pertinente do que a que concebe o universo da arquitetura e da construção como "campo", isto é, que leva em conta as práticas de todos os envolvidos com o poder social de construir lengenheiros, construtores, arquitetos, agentes imobiliários, publicitários, poderes públicos), suas posições relativas e respectivas tomadas de posição num universo de produtores-adversários.

Nessa perspectiva, a compreensão do sistema de preferências orientado pelo "charme do antigo" e do (falso) tradicional, mesmo que sob a forma da imitação grosseira, exige que se considere a atuação de cada uma das construtoras envolvidas na propagação dessas edificações no interior do campo em que se movem todos os construtores vistos em conjunto. Ou seja, na trilha dessa sociologia da cultura dirigida ao mundo da arquitetura, deve-se partir do levantamento das formas por meio das quais os propagadores de um tipo de projeto se diferenciam de seus concorrentes na luta pelo monopólio da legitimidade em matéria de habitação, determinar quais são os trunfos específicos responsáveis por atribuir a cada um uma posição determinada no campo e, em seguida, averiguar se os que dominam o mercado são os mais bem sucedidos na fabricação industrial de prédios de aparência tradicional, os que mais tiram partido das relações de homologia existentes entre os habitus dos compradores e dos vendedores e, por fim, os que mais honram as disposições pré-existentes da clientela. 


\section{REFERÊNCIAS}

ALLÉGRET, Jacques; BERTRAND, Régis; DEBARRE, Anne; ACCORSI, Florence. Trajectoires professionnelles: esquisse du champ de l'architecture. Paris: École d'Architecture ParisVillemin, 1989.

BAILLY, Jean-Christophe. Préface. In: LOYER, François. Paris XIXe siècle: l'immeuble et la rue. Paris: Hazan, 1987.

BARBE, Bernard; DUCLENT, Alain. Le vécu de l'architecture. Paris: Ministère de l'équipement, du logement, de l'aménagement du territoire et des transports, 1986.

BARROS, Mariana; MARTÍ, Silas. Arquitetos criticam novo neoclássico em São Paulo. Folba de São Paulo, São Paulo, 06/07/2009. Disponível em <http://www1.folha.uol.com.br/fsp/ ilustrad/fq0609200910.htm>, acesso em 02/09/2010.

BERNARD, Lise. Le capital culturel non certifié comme mode d'accès aux classes moyennes: l'entregent des agents immobiliers. Actes de la recherche en sciences sociales, Paris, n. 191192, p. 68-85, 2012.

BIAU, Véronique. La consécration en architecture: l'émergence de nouvelles élites architecturales en France. Tese (Doutorado em Sociologia) - École des Hautes Études en Sciences Sociales, Paris, 2000.

BOURDIEU, Pierre. La distinction: critique sociale du jugement. Paris: Minuit, 1979.

Les structures sociales de l'économie. Paris: Seuil, 2000.

Esboço de auto-análise. São Paulo: Companhia das Letras, 2005 [2002].

BOURDIEU, Pierre; DELSAUT, Yvette. O costureiro e sua grife: contribuição para uma teoria da magia. In: BOURDIEU, Pierre. A produção da crença: contribuição para uma economia dos bens simbólicos, $3^{\text {a }}$ ed. Porto Alegre: Zouk, 2006 [1975].

COXE, Weld et al. Success Strategies for Design Professionals Superpositioning for Architecture E Engineering Firms. St. Louis: McGraw Hill, 1990.

DELLHEIM, Charles. The Face of the Past: the Preservation of the Medieval Inheritance in Victorian England. Cambridge: Cambridge University Press, 1982.

DOWLING, Elisabeth Meredith. New Classicism: The Rebirth of Traditional Architecture. Nova York: Rizzoli, 2004.

DURAND, José Carlos. Arte, privilégio e distinção. Artes plásticas, arquitetura e classe dirigente no Brasil, 1855/1985. São Paulo: Perspectiva / Edusp, 1989.

ELEB, Monique; NIVET, Soline; VIOLEAU, Jean-Louis. L'architecture entre goût et opinion: construction d'un parcours et construction d'un jugement. Paris: Laboratoire Architecture, Culture et Sociétés / École Nationale Supérieure d'Architecture, 2005.

FICHER, Sylvia. Anotações sobre o pós-modernismo. Projeto, São Paulo, n. 74, p. 35-42, 1985. 
Reflexões sobre o pós-modernismo. $M D C$, Belo Horizonte / Brasília, n. 4, p. 3-17, 2008. Disponível em <http://revistamdc.files.wordpress.com/2008/12/mdc04-txt-01.pdf>, acesso em 19/09/2011.

FRANCASTEL, Pierre. Imagination et réalité dans l'architecture civile du Quattrocento. Paris, Extrait d'Hommage à Lucien Fèbvre (mimeo), 1964, p. 195-206.

GOMBRICH, Ernst Hans. La force de l'habitude. In: Gombrich: l'essentiel. Écrits sur l'art et la culture. Paris: Phaidon, 2003 [1996]. p. 223-256.

HELVÉCIA, Heloísa. Passado presente: compradores adoram, arquitetos odeiam, e o estilo neoclássico vai povoando a paisagem paulistana. Revista da Folba (Morar), São Paulo, 30/05/2008. Disponível em <http://sombras-eletricas.blogspot.com/2008/06/praganeoclssica.html>, acesso em 02/09/2010.

HUET, Bernard. Anachroniques d'architecture. Bruxelas: AAM Éditions, 1981.

JAMESON, Fredric. Pós-modernidade e sociedade de consumo. Novos Estudos Cebrap, São Paulo, n. 12, p. 16-26, 1985.

Arquitetura: equivalentes espaciais no sistema mundial. In: Pósmodernismo: a lógica cultural do capitalismo tardio. São Paulo: Ática, 1996 [1991]. p. 119148.

JENCKS, Charles. Post-Modernism: The New Classicism in Art and Architecture. Londres: Academy Editions, 1987.

KRIER, Leon. Quelles conclusions doit-on tirer de la mort des arts et de l'architecture ? In: Quatremère de Quincy. De l'imitation (1823). Paris: AAM Éditions, 1980.

LOYER, François. Paris XIXe siècle: l'immeuble et la rue. Paris: Hazan, 1987.

MARINS, Paulo César Garcez. Habitação e vizinhança: limites da privacidade no surgimento das metrópoles brasileiras. In: SEVCENKO, Nicolau (org.); NOVAIS, Fernando A (dir.). História da vida privada no Brasil, v. 3 (Da belle époque à era do rádio). São Paulo: Companhia das Letras, 1998.

MARTINON, Jean-Pierre. Fonctions symboliques et types d'architectes. La Nouvelle Critique, numéro spécial, 78 bis, 1974.

MAYER, Arno. A força da tradição: a persistência do Antigo Regime. São Paulo: Companhia das Letras, 1990 [1983].

MOULIN, Raymonde et al. Les architectes. Métamorphose d'une profession libérale. Paris: Calmann Lévy, 1973.

OSTROWETSKY, Sylvia; BORDREUIL, Jean Samuel. Le néo-style régional. Paris: Dunod, 1980.

PINTO, Louis. Déconstruire Beaubourg: art, politique et architecture. Genèses, Paris, n. 6, p. 98-124, dez. 1991. 
REIS FILHO, Nestor Goulart. Quadro da arquitetura no Brasil, $8^{\mathrm{a}}$ ed. São Paulo: Perspectiva, 1987.

REQUINTE da arquitetura francesa. Revista Perspectiva, n. 112, set. 2002. Disponível em http://www.novomilenio.inf.br/real/ed112.htm, acessado em 30/09/2010.

SCHORSKE, Carl E. Fin-de-Siècle Vienna: Politics and Culture. Nova York: Vintage Books, 1981.

SERAPIÃO, Fernando. Os edifícios-fantasmas e seus ornamentos delinquentes. Projeto Design, São Paulo, n. 290, abr. 2004. Disponível em <http://www.arcoweb.com.br/artigos/fernandoserapiao-os-edificios-fantasmas-20-04-2004.html>, acesso em 02/09/2010.

Projetos devem ser democráticos e expressar a nossa época. Folba de São Paulo, São Paulo, 22/05/2011, p. C1-C3.

VILLA, Simone Barbosa. O produto imobiliário paulistano: uma crítica à produção de apartamentos ofertados no mercado imobiliário a partir de 2000, 2006 (mimeo). Disponível em <http://www.lares.org.br/2006/artigo\%20Simone\%20Villa\%20vfinal.doc>, acesso em $06 / 09 / 2010$.

VIOLEAU, Jean-Louis. Les architectes et mai 68. Paris: Éditions Recherches, 2005.

WARCHAVCHIK, Gregori. Arquitetura do século XX e outros escritos. São Paulo: Cosac Naif, 2006.

WOLFF, Sylvia Ferreira Santos. Jardim América: o primeiro bairro-jardim de São Paulo e sua arquitetura. São Paulo: Edusp / Fapesp / Imprensa Oficial do Estado, 2001. 